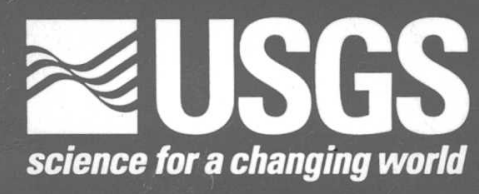

In cooperation with the

Maryland Department of Natural Resources

Tidewater Ecosystem Assessment

\title{
Nutrient and Suspended-Sediment Concentrations, Trends, Loads, and Yields From the Nontidal Part of the Susquehanna, Potomac, Patuxent, and Choptank Rivers, 1985-96
}

Water-Resources Investigations Report 98-4177 



\section{Nutrient and Suspended-Sediment Concentrations, Trends, Loads, and Yields From the Nontidal Part of the Susquehanna, Potomac, Patuxent, and Choptank Rivers, 1985-96}

by Linda C. Darrell, Brenda Feit Majedi, Joy S. Lizárraga, and Joel D. Blomquist

Water-Resources Investigations Report 98-4177

In cooperation with the

Maryland Department of Natural Resources

Tidewater Ecosystem Assessment 
U.S. Department of the Interior

BRUCE BABBITT, Secretary

U.S. Geological Survey

Charles G. Groat, Director

The use of trade, product, or firm names in this report is for descriptive purposes only and does not imply endorsement by the U.S. Geological Survey.

For additional information contact:

District Chief

U.S. Geological Survey, WRD

8987 Yellow Brick Road

Baltimore, MD 21237

Copies of this report can be purchased from:

U.S. Geological Survey

Branch of Information Services

Box 25286

Denver, CO 80225-0286 


\section{CONTENTS}

Abstract.

Introduction.

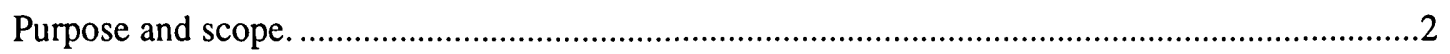

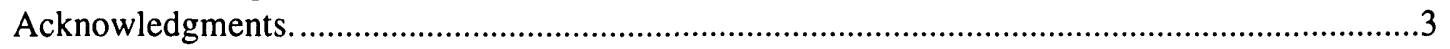

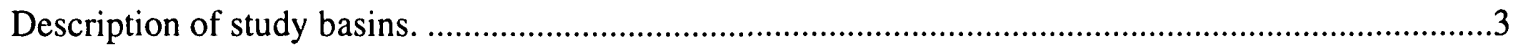

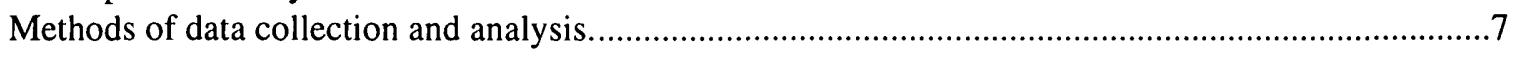

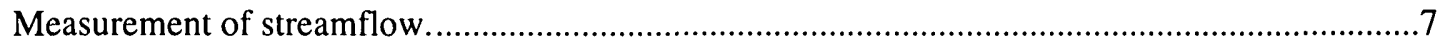

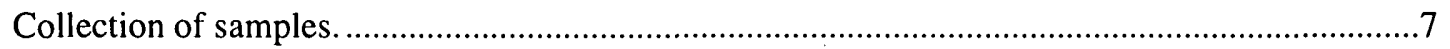

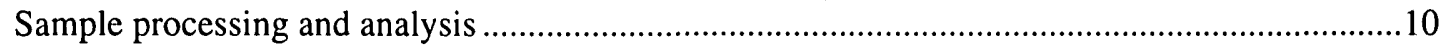

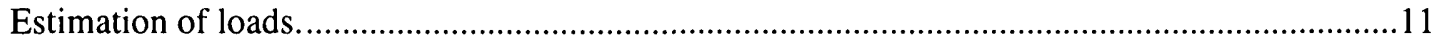

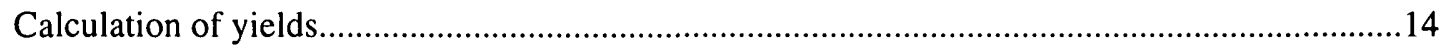

Analysis of trends.

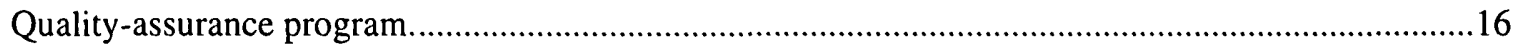

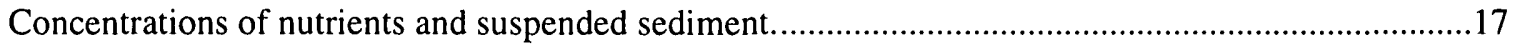

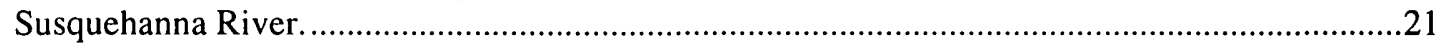

Potomac River.

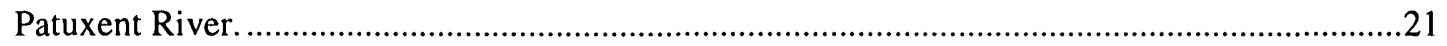

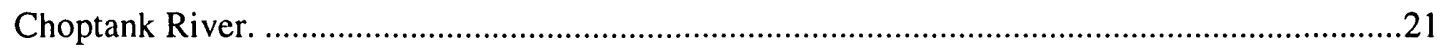

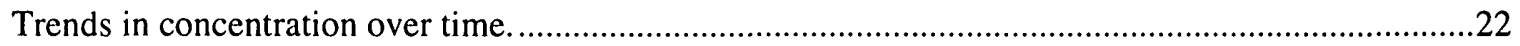

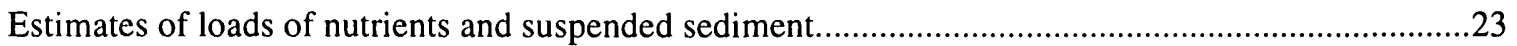

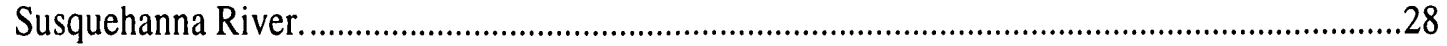

Potomac River.

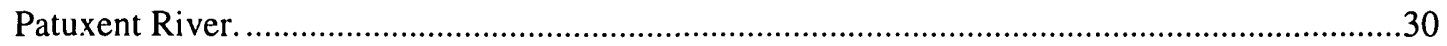

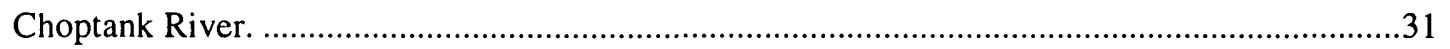

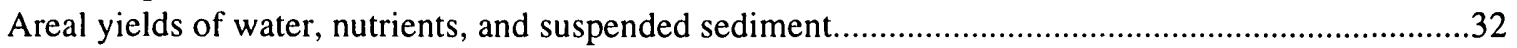

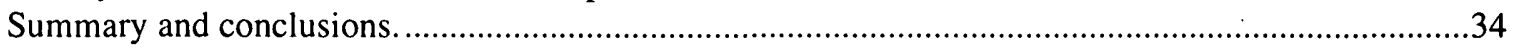

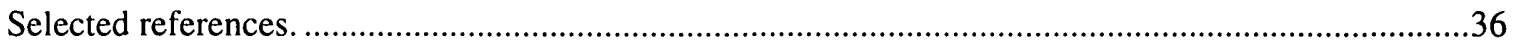

\section{Figures}

1. Map of Chesapeake Bay Basin study area showing drainage basins and locations of River-Input Monitoring Program stations.

2. Graph of annual mean streamflow during the study period at the Susquehanna, Potomac, Patuxent, and Choptank Rivers, 1985-96. ........................................8

3. Graphs showing the residuals of regression models for concentrations of nitrite plus nitrate at Potomac River at Washington, D.C., with (A) streamflow, (B) time, and (C) seasonal terms excluded and included as regression parameters.

4. Graph showing residuals and model-predicted concentrations of nitrite plus nitrate for the Potomac River at Washington, D.C.

5. Graph showing trends in flow-adjusted concentrations of nutrients and suspended sediment at four river-monitoring stations in the Chesapeake Bay Basin, 1985-96. 


\section{Figures-Continued}

6-9. Graphs showing monthly loads of nutrients and suspended sediment and daily mean streamflow at the:

6. Susquehanna River at Conowingo, Md., 1985-96........................................................28

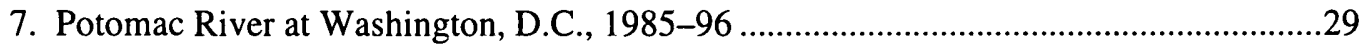

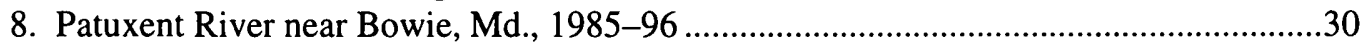

9. Choptank River near Greensboro, Md., 1985-96 ............................................................31

10. Boxplots showing annual nutrient, suspended-sediment, and water yields from the nontidal parts of the Susquehanna, Potomac, Patuxent, and Choptank River Basins, 1985-96.

\section{Tables}

1. Summary of land cover in the Susquehanna, Potomac, Patuxent, and Choptank River Basins.

2. Location of the River-Input Monitoring Program stations

in Maryland and Washington, D.C., and associated drainage areas.

3. Streamflow conditions for the River-Input Monitoring Program stations in Maryland and Washington, D.C

4. Analytical methodologies of the U.S. Geological Survey National Water-Quality Laboratory and Occoquan Watershed Monitoring Laboratory, 1985-96.

5-6. Interpretation of variability in concentration data:

5. Due to variations in streamflow.

6. Over time.

7. Summary statistics for selected water-quality constituents monitored at the River-Input Monitoring Program stations in Maryland and Washington, D.C.,1985-96..

8. Seven-parameter regression-model coefficient estimates of parameters for the River-Input Monitoring Program stations in Maryland and Washington, D.C., 1985-96.

9. Point-source inputs of nitrogen and phosphorus upstream from the Susquehanna, Potomac, and Patuxent River monitoring stations, 1985,1995 , and percent reduction.

10-13. Estimated annual loads of nutrients and suspended sediment at the:

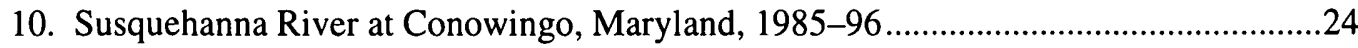

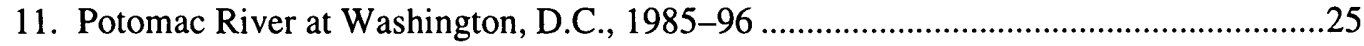

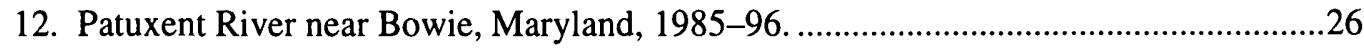

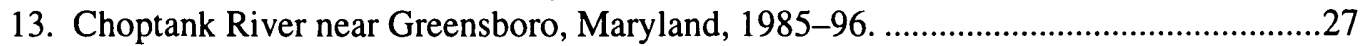




\begin{tabular}{|c|c|c|}
\hline Multiply & By & To obtain \\
\hline \multicolumn{3}{|c|}{ Length } \\
\hline $\begin{array}{l}\text { inch (in.) } \\
\text { inch (in.) } \\
\text { mile (mi) }\end{array}$ & $\begin{array}{c}2.54 \\
25.4 \\
1.609\end{array}$ & $\begin{array}{l}\text { centimeter } \\
\text { millimeter } \\
\text { kilometer }\end{array}$ \\
\hline \multicolumn{3}{|c|}{ Area } \\
\hline $\begin{array}{l}\text { square mile }\left(\mathrm{mi}^{2}\right) \\
\text { square mile }\left(\mathrm{mi}^{2}\right)\end{array}$ & $\begin{array}{l}259.0 \\
2.590\end{array}$ & $\begin{array}{l}\text { hectare } \\
\text { square kilometer }\end{array}$ \\
\hline \multicolumn{3}{|c|}{ Flow rate } \\
\hline cubic foot per second $\left(\mathrm{ft}^{3} / \mathrm{s}\right)$ & 0.02832 & cubic meter per second \\
\hline
\end{tabular}

Sea Level: In this report, "sea level" refers to the National Geodetic Vertical Datum of 1929-a geodetic datum derived from a general adjustment of the first-order level nets of the United States and Canada, formerly called Sea Level datum of 1929.

Temperatures in degrees Celsius $\left({ }^{\circ} \mathrm{C}\right)$ may be converted to degrees Fahrenheit $\left({ }^{\circ} \mathrm{F}\right)$ as follows:

$$
{ }^{\circ} \mathrm{F}=1.8\left({ }^{\circ} \mathrm{C}\right)+32
$$

Temperatures in degrees Fahrenheit $\left({ }^{\circ} \mathrm{F}\right)$ may be converted to degrees Celsius $\left({ }^{\circ} \mathrm{C}\right)$ as follows:

$$
{ }^{\circ} \mathrm{C}=\left({ }^{\circ} \mathrm{F}-32\right) / 1.8
$$

Chemical concentration in water is expressed in milligrams per liter $(\mathrm{mg} / \mathrm{L})$ or micrograms per liter $(\mu \mathrm{g} / \mathrm{L})$. 


\title{
Nutrient and Suspended-Sediment Concentrations, Trends,
}

\section{Loads, and Yields From the Nontidal Part of the Susquehanna, Potomac, Patuxent, and Choptank Rivers, 1985-96}

\author{
By Linda C. Darrell, Brenda Feit Majedi, Joy S. Lizárraga, and Joel D. Blomquist
}

\begin{abstract}
The Chesapeake Bay River-Input Monitoring Program was established to characterize the water quality of four major rivers in Maryland, and to quantify the load and the long-term trends in concentrations of nutrients (nitrogen and phosphorus) and suspended sediment transported from the nontidal part of each river to the Chesapeake Bay. As part of the River-Input Monitoring Program, nutrient and suspended-sediment data and streamflow data were collected from 1985 through 1996 at the Susquehanna, Potomac, Patuxent, and Choptank Rivers above the points of tidal influence. The data were used to determine the effectiveness of strategies aimed at reducing nutrients entering Chesapeake Bay from its tributaries.
\end{abstract}

Of the four rivers studied, the Patuxent River had the highest median concentrations of total nitrogen (2.6 milligrams per liter), total phosphorus ( 0.17 milligrams per liter), and suspended sediment (45 milligrams per liter) during the 12-year period. From 1985-96, flow-adjusted concentrations of total nitrogen decreased in all but the Potomac River, flow-adjusted concentrations of total phosphorus decreased in all four rivers, and flow-adjusted concentrations of suspended sediment decreased in all but the Susquehanna River.

The rivers that contributed the greatest amount of streamflow to Chesapeake Bay, the Susquehanna and Potomac, also contributed the greatest nutrient loads and suspended-sediment loads to the Bay. The
Susquehanna River transported the highest average-annual loads of total phosphorus (4.7 million pounds per year) and total nitrogen (146 million pounds per year), while the Potomac River transported the highest average-annual load of suspended sediment ( 4.1 billion pounds per year) to the Bay.

Annual loads and annual mean streamflow were normalized by basin drainage area to account for some of the hydrologic differences among the river basins. An increase in precipitation from south to north is still apparent, however, when comparing the water yields among river basins. The Susquehanna River Basin had the highest median annual water yield during the study period; the other three basins all had similar water yields. The Susquehanna River and the Patuxent River had the highest median annual yields of nitrogen during the study period. The Patuxent River also had the highest median annual yield of total phosphorus during the study period, while the Potomac River had the highest median yield of suspended sediment.

Annual yields of total phosphorus and suspended sediment from the Susquehanna and the Choptank River Basins are lower than those from the Potomac and Patuxent River Basins. These relatively small yields from the Susquehanna River may be due to the location of the sampling station below 
Conowingo Dam. A series of three dams upstream trap a large percentage of sediment and total phosphorus carried by the Susquehanna River to Chesapeake Bay.

\section{Introduction}

The Chesapeake Bay is the largest estuary in the Nation, draining approximately

65,000 square miles $\left(\mathrm{mi}^{2}\right)$ of Delaware, the District of Columbia, Maryland, New York, Pennsylvania, Virginia, and West Virginia. The estuary stretches nearly $200 \mathrm{mi}$ from its origin at the confluence of the Susquehanna, Northeast, and Elk Rivers in northeastern Maryland to its outlet to the Atlantic Ocean in southeastern Virginia. More than 15 million people live within the watershed that includes the large metropolitan centers of Washington, D.C., Baltimore, Md., Richmond, Va., and Hampton Roads, Va. The Chesapeake Bay provides thousands of jobs to workers in the fishing and shellfish, recreation, and shipping industries. Its waters and coastal areas support an abundant and diverse wildlife population.

Excess nutrients enter the Chesapeake Bay from "nonpoint" sources such as airborne pollution, runoff from city streets, and fertilizerladen farmlands, as well as from "point" sources such as sewage-treatment plants. Suspended sediment is carried into Chesapeake Bay by tributary streams as a result of erosion and runoff from farmland, streambanks, construction sites, cities, and suburbs. In addition, phosphorus and many toxic contaminants, such as trace metals and pesticides, attach to sediment particles that are carried downstream and deposited into the Bay.

The living resources of the Chesapeake Bay have been degraded as a result of increases in the amount of nitrogen and phosphorus compounds (nutrients) and sediment in streams tributary to the Bay (U.S. Environmental Protection Agency, 1995). An overabundance of algae can result from elevated concentrations of certain nutrients in the Bay. This overabundance of algae results in cloudy water, which reduces the extent of submerged aquatic vegetation used by shellfish larva and fish for food and protection. Excess sediment also clouds the water and coats the leaves of the aquatic vegetation, depriving them of sunlight needed for plant growth. Subsequent death and decay of the algae depletes the dissolved oxygen in the water and can result in the loss of habitat and the death of fish, shellfish, and other aquatic organisms.

In order to address the problems related to increases in nutrients and suspended sediment entering the Chesapeake Bay, the District of Columbia and the States of Maryland, Pennsylvania, and Virginia signed the Chesapeake Bay Agreement in 1987. The agreement commits these States to work together with Federal and local agencies toward a 40 -percent reduction in controllable nitrogen and phosphorus loads reaching the Chesapeake Bay by the year 2000, based on 1985 levels (U.S. Environmental Protection Agency, 1988). Achievement of this goal is predicted to improve the low dissolvedoxygen conditions, reduce the extent and duration of algae blooms, and improve the clarity and water quality of the Chesapeake Bay.

In order to assess the effectiveness of nutrientand sediment-reduction programs that were started in the early and mid-1980's, the State of Maryland, in cooperation with the Metropolitan Washington Council of Governments (MWCOG), and the U.S. Geological Survey (USGS) began the Chesapeake Bay River-Input Monitoring Program in 1983. The purpose of the monitoring program is to describe the water quality and quantify the load and long-term trends in concentrations of nutrients and suspended sediment entering the Chesapeake Bay from the Susquehanna, Potomac, Patuxent, and Choptank Rivers at locations in Maryland and Washington, D.C. The four rivers were chosen for monitoring because of their varying sizes and land uses in the contributing drainage areas, and because they provide approximately 70 percent of the streamflow to Chesapeake Bay (Bue, 1968).

In 1988, the USGS, in cooperation with the Virginia Department of Environmental Quality (VaDEQ) expanded the Chesapeake Bay RiverInput Monitoring Program to include the James, Rappahannock, Appomattox, Pamunkey, and Mattaponi Rivers in Virginia. The nine Maryland and Virginia monitoring stations collectively contribute approximately 90 percent of the streamflow from the nontidal part of the 65,000-mi ${ }^{2}$ Chesapeake Bay Basin.

\section{Purpose and Scope}

The purpose of this report is to estimate and analyze the concentrations, trends in flow-adjusted concentrations, loads, and yields of nutrients and suspended sediment in four major tributaries to the 
Chesapeake Bay, on the basis of data collected for the Chesapeake Bay River-Input Monitoring Program at locations in Maryland and Washington, D.C. The water-quality data used in the analyses made for this report are derived from the analysis of water samples collected from the Susquehanna River at Conowingo, Md., the Potomac River at Washington, D.C., the Patuxent River near Bowie, Md., and the Choptank River near Greensboro, Md., during 1985-96. Waterquality constituents evaluated include nitrite plus nitrate as nitrogen; total Kjeldahl nitrogen as nitrogen; total nitrogen, as the sum of nitrite plus nitrate and total Kjeldahl nitrogen, as nitrogen; total phosphorus; dissolved phosphorus; dissolved ortho-phosphorus; and suspended sediment.

\section{Acknowledgments}

The authors gratefully acknowledge the contribution of numerous USGS hydrologic technicans, who collected the water samples and streamflow data that serve as the basis for this report. Much of this data was collected during nights, weekends, holidays, and during adverse weather conditions. Their dedication and technical expertise is truly appreciated.

The authors wish to thank Harry Post of the Occoquan Watershed Monitoring Laboratory (OWML) for hydrologic data-collection efforts and technical support. The authors also gratefully acknowledge the cooperation and assistance of the staff of the Philadelphia Electric Company (PECO) during sampling at the Susquehanna River Conowingo Dam monitoring site. Support for the River-Input Monitoring Program and preparation of this report is through an interagency cooperative agreement between the Maryland Department of Natural Resources and the U.S. Geological Survey.

\section{Description of Study Basins}

The four major river basins selected for study (fig. 1) contribute water, nutrients, and suspended sediment to Chesapeake Bay from a wide range of land cover (table 1), hydrologic, and geologic conditions. The water-quality monitoring stations on each of the rivers are at or near the Fall Line of the Susquehanna, Potomac, and Patuxent Rivers, and above the point of tidal influence on the Choptank River. The Fall Line is the boundary between the Piedmont and the Coastal Plain Physiographic Provinces. Each of the water- quality monitoring stations was located at or near existing USGS stream-gaging stations (table 2).

The Susquehanna River is the Chesapeake Bay's largest tributary, contributing approximately 52 percent of the total freshwater flow to the Bay (Bue, 1968). The Susquehanna drains $27,510 \mathrm{mi}^{2}$; approximately $27,100 \mathrm{mi}^{2}$ of the basin drains to the monitoring station. The headwaters of the Susquehanna River are in the Appalachian Plateau of New York and Pennsylvania. The river flows through the Valley and Ridge Province across the Piedmont Plateau and enters Chesapeake Bay at the Fall Line. Forest and agriculture are the primary land uses in the Susquehanna River Basin (Vogelmann and others, 1998). The rolling hills and valleys in the southern part of the basin contain the majority of the population centers and some of the most productive agricultural land in the Nation (Lindsey and others, 1997).

The water-quality monitoring station and stream-gaging station on the Susquehanna River are located at Conowingo Dam in Conowingo, Md. Conowingo Dam is the largest and farthest downstream of three hydroelectric dams (Safe Harbor, Holtwood, and Conowingo) on the lower Susquehanna River. Lake Clarke formed by Safe Harbor Dam, Lake Aldred formed by Holtwood Dam, and Conowingo Reservoir formed by Conowingo Dam, have been filling with sediment since the dams were constructed. Safe Harbor and Holtwood Dams have reached their capacity to store sediments and generally no longer trap sediments and sediment-associated nutrients carried by the river (Langland and Hainly, 1997). Conowingo Dam traps approximately 70 percent of the suspended-sediment load, 45 percent of the phosphorus load, and 2 percent of the nitrogen load that would otherwise be discharged to the Chesapeake Bay (Ott and others, 1991). In addition, Gross and others (1978) suggested that major floods [streamflows greater than 400,000 cubic feet per second $\left.\left(\mathrm{ft}^{3} / \mathrm{s}\right)\right]$ resuspend and transport previously deposited sediment and sediment-associated nutrients from the reservoirs. Lang (1982) also concluded that streamflows greater than $400,000 \mathrm{ft}^{3} / \mathrm{s}$ may transport nutrient and suspended-sediment loads to the Bay that are well in excess of loads transported by the Susquehanna River at Harrisburg, $\mathrm{Pa}$., which is located above the three dams. 


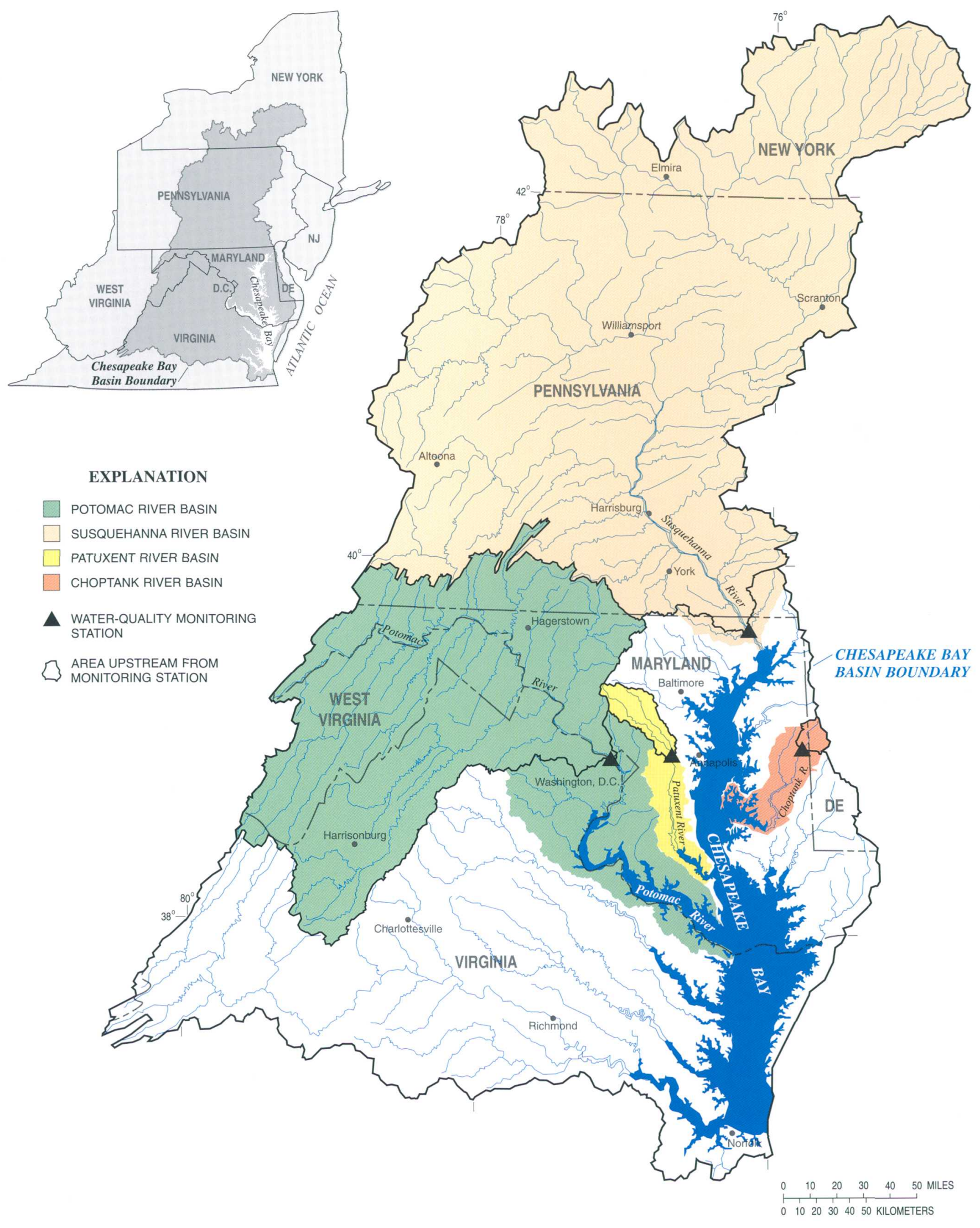

Figure 1. Chesapeake Bay Basin study area showing drainage basins and location of River-Input Monitoring Program stations. 
Table 1. Summary of land cover in the Susquehanna, Potomac, Patuxent, and Choptank River Basins

[From Vogelmann, J.E., Sohl, T.L., Campbell, P.V., and Shaw, D.M., 1998. Regional land cover characterization using Landsat Thematic Mapper data and ancillary data sources, Third EMAP Research Symposium, April 8-11, 1997, Environmental Monitoring and Assessment. Data is commonly referred to as the MRLC (Multi-Resolution Land Characteristics) data set. All measurements are in percent. $<$, less than]

\begin{tabular}{|c|c|c|c|c|c|c|c|c|}
\hline $\begin{array}{l}\text { River } \\
\text { name }\end{array}$ & Location & $\begin{array}{l}\text { Open } \\
\text { water }\end{array}$ & Residential $^{\text {a }}$ & $\begin{array}{l}\text { Commercial/ } \\
\text { Industrial }\end{array}$ & Agriculture & Forest ${ }^{c}$ & Wetland $^{d}$ & Other $^{\mathrm{e}}$ \\
\hline \multirow[t]{2}{*}{ Susquehanna } & Basin & 1.0 & 2.0 & $<1$ & 29.0 & 66.0 & $<1$ & $<1$ \\
\hline & $\begin{array}{l}\text { Above } \\
\text { monitoring } \\
\text { station }\end{array}$ & 1.1 & 1.9 & $<1$ & 28.7 & 66.7 & $<1$ & $<1$ \\
\hline \multirow[t]{2}{*}{ Potomac } & Basin & 4.0 & 5.0 & 0.5 & 32 & 57 & 1 & $<1$ \\
\hline & $\begin{array}{l}\text { Above } \\
\text { monitoring } \\
\text { station }\end{array}$ & 0.7 & 2.6 & $<1$ & 34.7 & 60.8 & $<1$ & $<1$ \\
\hline \multirow[t]{2}{*}{ Patuxent } & Basin & 6.0 & 10 & 1.0 & 35 & 42 & 5.5 & $<1$ \\
\hline & $\begin{array}{l}\text { Above } \\
\text { monitoring } \\
\text { station }\end{array}$ & 1.2 & 13 & 1.1 & 41.4 & 37.6 & 4.8 & $<1$ \\
\hline \multirow[t]{2}{*}{ Choptank } & Basin & 15.6 & 2.2 & $<1$ & 49 & 22 & 10.6 & $<1$ \\
\hline & $\begin{array}{l}\text { Above } \\
\text { monitoring } \\
\text { station }\end{array}$ & $<1$ & 1.0 & $<1$ & 50 & 28.6 & 20 & $<1$ \\
\hline
\end{tabular}

a. Includes low and high density residential and transitional barren.

b. Includes pasture, hay, row crop, and other grasses.

c. Includes evergreen, mixed and deciduous forest.

d. Includes woody and emergent wetland.

c. Quarry/strip mine/gravel pit.

The Potomac River is Chesapeake Bay's second largest tributary, contributing approximately 18 percent of the total freshwater flow to the Bay (Bue, 1968). The Potomac River drains $14,670 \mathrm{mi}^{2}$; approximately $11,570 \mathrm{mi}^{2}$ drains to the monitoring station. The Potomac River flows through seven physiographic provinces and subprovinces-the Appalachian Plateau, Valley and Ridge, Great Valley, Blue Ridge, Piedmont, Triassic Lowlands, and the Atlantic Coastal Plain. Forest and agriculture are the dominant land uses in the basin above the monitoring station (Lizárraga, 1997). The Potomac River waterquality monitoring station is located at
Chain Bridge in Washington, D.C., upstream from the municipal wastewater discharges of the Metropolitan Washington, D.C., area. The USGS stream-gaging station for the Potomac River at Little Falls Dam is located 1.2 miles upstream from the water-quality monitoring station.

The Patuxent River Basin drains about $932 \mathrm{mi}^{2}$; approximately $348 \mathrm{mi}^{2}$ drains to the monitoring station. At its mouth, the river contributes 1.4 percent of the freshwater flow to Chesapeake Bay. The Patuxent River flows through the Piedmont Physiographic Province and the Atlantic Coastal Plain. Land use above the 
Table 2. Location of the River-Input Monitoring Program stations in Maryland and Washington, D.C., and associated drainage areas

[USGS, U.S. Geological Survey; ' , degree; ', minute; ", second]

\begin{tabular}{|c|c|c|c|c|c|c|}
\hline $\begin{array}{l}\text { River } \\
\text { name }\end{array}$ & $\begin{array}{l}\text { USGS } \\
\text { Station } \\
\text { no. }\end{array}$ & $\begin{array}{l}\text { Station } \\
\text { location }\end{array}$ & $\begin{array}{l}\text { Latitude } \\
\left({ }^{\circ}, "\right)\end{array}$ & $\begin{array}{l}\text { Longitude } \\
\left({ }^{\circ}{ }^{\prime} \text { " }\right)\end{array}$ & $\begin{array}{l}\text { River basin } \\
\text { drainage areas } \\
\text { (square miles) }\end{array}$ & $\begin{array}{l}\text { River basin } \\
\text { drainage area } \\
\text { above station } \\
\text { (square miles) }\end{array}$ \\
\hline Susquehanna & 01578310 & $\begin{array}{l}\text { Susquehanna River } \\
\text { at Conowingo, Md. }\end{array}$ & 393931 & 761028 & 27,510 & 27,100 \\
\hline \multirow[t]{2}{*}{ Potomac } & 01646580 & $\begin{array}{l}\text { Potomac River } \\
\text { at Chain Bridge, }{ }^{a} \\
\text { at Washington, D.C. }\end{array}$ & 385546 & 770702 & 14,670 & 11,570 \\
\hline & 01646500 & $\begin{array}{l}\text { Potomac River (at Little } \\
\text { Falls Dam) } \\
\text { near Washington, D.C. }\end{array}$ & 385658 & 770740 & 14,670 & 11,560 \\
\hline Patuxent & 01594440 & $\begin{array}{l}\text { Patuxent River (at } \\
\text { Governor's Bridge) } \\
\text { near Bowie, Md. }\end{array}$ & 385721 & 764136 & 932 & 348 \\
\hline Choptank & 01491000 & $\begin{array}{l}\text { Choptank River } \\
\text { near Greensboro, Md. }\end{array}$ & 385950 & 754710 & 795 & 112 \\
\hline
\end{tabular}

a.Water-quality data only.

b. Streamflow data only.

monitoring station ranges from sparsely populated agricultural regions in the northern extreme to densely populated urban and residential areas in the central part of the basin (Preston and Summers, 1996).

The water-quality monitoring station on the Patuxent River is located on the bridge of Governor's Bridge Road near Bowie, Md. Several large wastewater-treatment plants are immediately upstream from the monitoring station, possibly affecting water quality at the site. The USGS stream-gaging station for the Patuxent River is located at the Route 50 (John Hanson Highway) Patuxent River bridge. The stream-gaging station is approximately 0.3 miles upstream of the Governor's Bridge water-quality monitoring station.
The Choptank River is the smallest of the four rivers studied in the network. The Choptank River Basin drains about $795 \mathrm{mi}^{2}$; approximately $112 \mathrm{mi}^{2}$ drains to the monitoring station. The combined rivers from Maryland's Eastern Shore contribute approximately 6 percent of the freshwater inflow to Chesapeake Bay; the Choptank River at its mouth contributes 1.2 percent of the freshwater flow to the Bay. The Choptank River Basin lies entirely within the Atlantic Coastal Plain. Land use above the waterquality monitoring station is primarily agricultural, with a large percentage of forest and wetland (Vogelmann and others, 1998). On the basis of land use, slope, and soils, the part of the Choptank River Basin analyzed for this study has been classified as a "poorly drained" basin 
(Phillips and Bachman, 1996). Poorly drained uplands generally yield lower concentrations of nutrients than "well-drained uplands" on the Eastern Shore. The water-quality monitoring station and the USGS stream-gaging station on the Choptank River are located at the bridge on Red Bridges Road in Christian Park near Greensboro, Md.

A 46-year record for total streamflow to Chesapeake Bay was set in 1996, mainly due to floods that occurred in January (U.S. Geological Survey, data accessed on July 30, 1998). Although high-flow records for each of the monitored rivers were not exceeded in 1996, each river did set new records for the second-highest peak flow and daily-mean flow on record during the study period (table 3). During 1985-96, highest average mean-daily flows occurred on the four rivers during the winter months (January through March), followed by the spring (April through June), fall (October through December) and summer months (July through September).

During the years 1985-92, annual mean-daily flow at the four river stations was at or below the long-term average, with the exception of 1989 , which was an above-average flow year for the Patuxent and Choptank Rivers, and 1990, which was an above-average flow year for the Susquehanna River (fig. 2). During the later years of the study period (1993-96), annual mean-daily flow at the four rivers was above average, with the exception of 1993 at the Choptank River, and 1995, when flow was below average at all four river stations (fig. 2).

\section{Methods of Data Collection and Analysis}

The methods used to measure streamflow and collect, process, and analyze water-quality samples are documented below. In addition, methods used to estimate and characterize constituent concentrations, loads, yields, and trends are described.

\section{Measurement of Streamflow}

Monitoring streamflow is important for several reasons. Concentration levels of nutrients and suspended sediment are often correlated to the amount of streamflow in a river. A measurement of streamflow also is needed to calculate the load, or mass, of nutrients and suspended sediment transported by a river.

Instantaneous and mean-daily flow data were calculated for the four River Input stream-gaging stations on the basis of periodic flow measure- ments and continuous 15 - or 30 -minute river-stage recordings. Streamflow measurements were made by USGS personnel using standard USGS streamgaging techniques (Buchanan and Somers, 1982). River stage was monitored and recorded automatically by use of a float and stilling-well system at the Susquehanna and Choptank River streamgaging stations and a STACOM gas-purge manometer system at the Potomac and Patuxent River stream-gaging stations. Specific details on the calculation of streamflow measurements are described in Carter and Davidian (1968).

\section{Collection of Samples}

Water samples for the River-Input Monitoring Program were collected by USGS at the Susquehanna, Patuxent, and Choptank Rivers, and by OWML, in cooperation with MWCOG, at the Potomac River during the period 1985-96. In addition, nutrient and suspended-sediment data were collected at the Susquehanna and Potomac Rivers from 1993-97, and at the Choptank River from 1987-90, as part of the USGS National Water-Quality Assessment (NAWQA) program. Water samples were collected at the Potomac, Patuxent, and Choptank monitoring stations as part of the USGS National Stream-Quality Accounting Network (NASQAN) during the period 1979-94, and at the Susquehanna River monitoring station during the period 1979-95.

As part of the River-Input Monitoring Program, USGS personnel collected water samples for analysis of nutrients and suspended sediment once or twice monthly during stable-flow conditions and over a range in stormflow conditions throughout the four seasons of each year. Personnel from OWML collected water samples for analysis of nutrient and total suspended solids at the Potomac River station during stable-flow conditions and during most storm events. The collection of samples during storms was emphasized because most river-borne nutrient and suspended-sediment load is associated with storm runoff.

A primary consideration in the collection of samples for analysis of nutrients and suspended sediment was to obtain samples representative of river conditions at the time of sampling. In order to collect representative samples, specific procedures were followed and specialized equipment was used. Nutrient and suspendedsediment samples were collected using either the Equal-Discharge-Increment (EDI) method or 


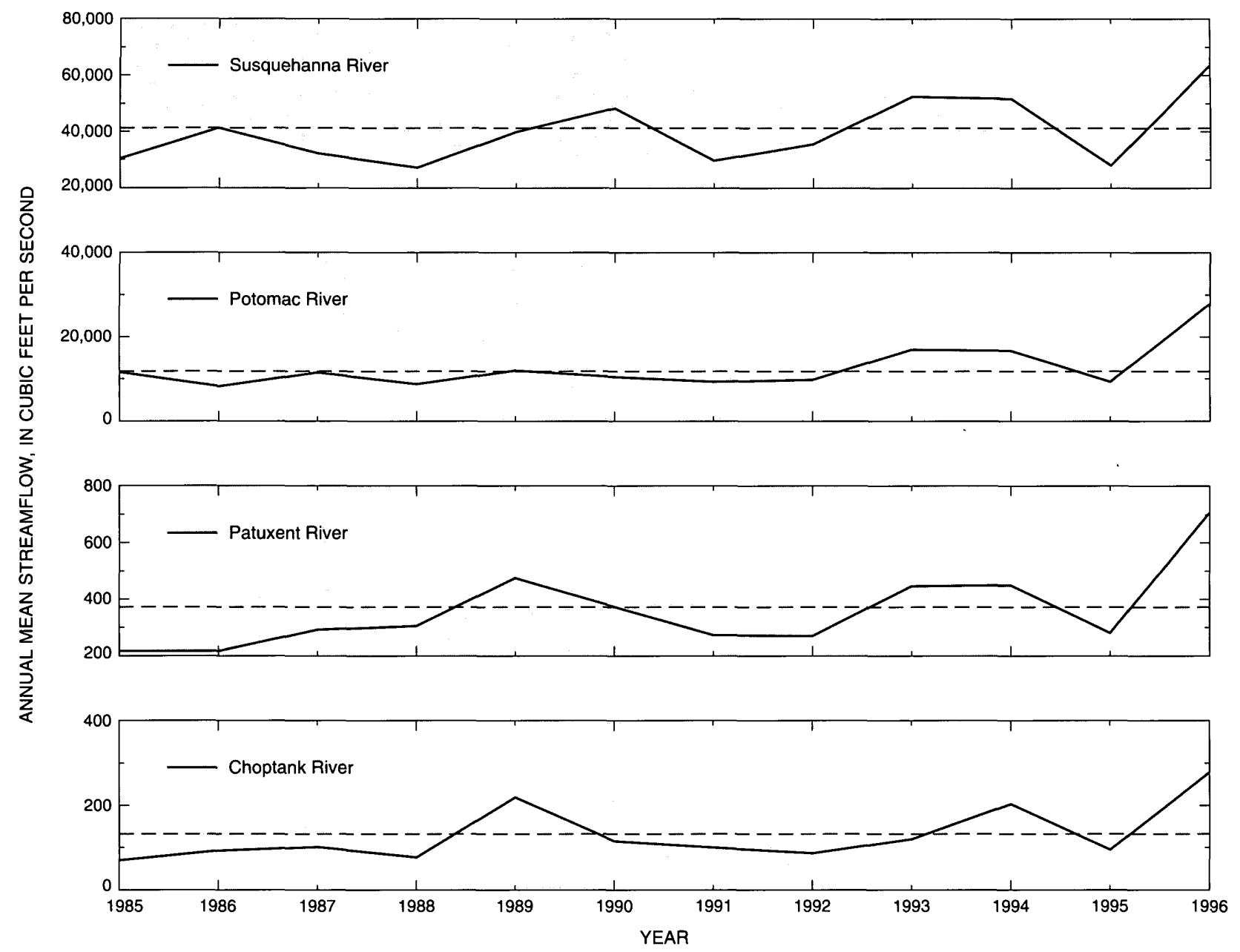

Figure 2. Annual mean streamflow during the study period at the Susquehanna, Potomac, Patuxent, and Choptank Rivers, $1985-96$. (The dashed line is the mean annual streamflow during the period of record at each site.)

the Equal-Transit-Rate (ETR) method (Guy and Norman, 1970). The EDI method, used at the Susquehanna and Potomac River monitoring stations, requires collecting samples of equal volume from the centroid of equal-discharge increments along the river cross section. The ETR method, used at the Patuxent and the Choptank River monitoring stations, requires collecting sample volumes proportional to the amount of flow at each of several equally spaced verticals along the cross section.

Using either the EDI or the ETR samplecollection method, two samples were collected from each sampling point along the river cross section. One set of the samples was collected for nutrient analysis and subsequently deposited into a holding device, referred to as a churn splitter. The churn splitter allowed subsamples to be withdrawn while maintaining a uniform distribution of suspended matter in the composited sample. The second set of samples was collected for suspended-sediment analysis and remained in their respective sample-collection bottles.

A weighted-bottle sampler, an isokinetic sampler, and a 2-liter ground-water bailer were used to collect the river samples. The weightedbottle sampler was used during base-flow conditions at each of the monitoring stations. 
Table 3. Streamflow conditions for the River-Input Monitoring Program stations in Maryland and Washington, D.C.

[Data obtained from 1948-96 continuous discharge records published in the annual U.S. Geological Survey Water-Resources

Data Reports; $\mathrm{ft}^{3} / \mathrm{s}$, cubic feet per second]

\begin{tabular}{|c|c|c|c|c|c|}
\hline Time of record & & $\begin{array}{l}\text { Mean-daily } \\
\text { streamflow } \\
\text { (minimum) } \\
\left(\mathrm{ft}^{3} / \mathrm{s}\right)\end{array}$ & $\begin{array}{l}\text { Mean-daily } \\
\text { streamflow } \\
\text { (mean) } \\
\left(\mathrm{ft}^{3} / \mathrm{s}\right)\end{array}$ & $\begin{array}{l}\text { Mean-daily } \\
\text { streamflow } \\
\text { (maximum) } \\
\left(\mathbf{f t}^{3} / \mathbf{s}\right)\end{array}$ & $\begin{array}{l}\text { Highest } \\
\text { instantaneous } \\
\text { peak flow } \\
\left(\mathrm{ft}^{3} / \mathrm{s}\right)\end{array}$ \\
\hline \multicolumn{6}{|c|}{ Susquehanna River (01578310) } \\
\hline Period of record & 1967-1996 & 269 & 41,210 & $1,120,000$ & $1,130,000$ \\
\hline Study period & $1985-1996$ & 821 & 40,008 & 622,000 & 909,000 \\
\hline \multicolumn{6}{|c|}{ Potomac River (01646500) } \\
\hline Period of record & $1959-1996$ & 121 & 11,740 & 334,000 & 359,000 \\
\hline Study period & $1985-1996$ & 514 & 12,674 & 326,000 & 347,000 \\
\hline \multicolumn{6}{|c|}{ Patuxent River (01594440) } \\
\hline Period of record & $1977-1996$ & 56 & 372 & 8,860 & ${ }^{\mathrm{a}} 31,100$ \\
\hline Study period & $1985-1996$ & 56 & 359 & 8,400 & 9,190 \\
\hline \multicolumn{6}{|c|}{ Choptank River (01491000) } \\
\hline Period of record & $1948-1996$ & 1.5 & 132 & 6,160 & 6,970 \\
\hline Study period & $1985-1996$ & 2.5 & 129 & 4,120 & 4,800 \\
\hline
\end{tabular}

a.Includes 1955-1977 peak flow record, which extends the continuous discharge period of record.

The isokinetic sampler was used during stormflow conditions at the Patuxent and Choptank Rivers. The sampler is heavy so that it can maintain a vertical position in the river as it is lowered down to the streambed and back up to the surface of the river. It is designed to allow river water to enter the sampler nozzle at the same velocity as the stream, permit the sampler nozzle to reach a point as close to the streambed as possible without disturbing the bottom sediment, and minimize disturbance to the flow pattern of the stream (Guy and Norman, 1970). The 2-liter ground-water bailer was used during stormflow conditions on the Susquehanna and Potomac Rivers. Although it was designed to collect water samples from a well, the bailer was used at the Susquehanna and Potomac Rivers because stormflow conditions produced streamflow velocities too high to be collected with either weighted-bottle or isokinetic samplers.

The OWML nutrient and suspended-sediment samples for the Potomac River were collected at a fixed point on the river using automatic sampling equipment. The automatic sampler was housed on the Washington, D.C., side of Chain Bridge. The primary consideration in locating the automatic sampling equipment at Chain Bridge was the requirement to extract representative samples of . 
the river flow at a variety of stages, ranging from base flow to extreme stormflow peaks. The river channel at Chain Bridge is relatively narrow and well mixed, and samples collected from the point sampler were comparable to samples collected from the cross section during all but extreme highflow conditions (Darrell and others, in press).

\section{Sample Processing and Analysis}

Samples for nutrient analysis collected by USGS personnel were composited in a pre-cleaned plastic Nalgene churn splitter. Subsamples for whole-water analysis were withdrawn from the churn splitter while churning the sample water at a continuous rate of 9 inches per second. The remaining sample was filtered on site for dissolved analysis using a 0.45 -micron, $142-\mathrm{mm}$ plate membrane filter (through November 1993), and a disposable 0.45-micron cartridge filter (after November 1993). Samples to be analyzed for nutrients were preserved with a mercuric chloride/ sodium chloride solution (through October 1994), and chilled to a temperature of $4^{\circ}$ Celsius.

Water samples collected by USGS personnel were analyzed for nutrients at the USGS National Water-Quality Laboratory (NWQL) in Denver, Colo., and were analyzed for suspended sediment at a USGS sediment laboratory in Lemoyne, Pa. Samples collected by OWML personnel from the Potomac River were analyzed by OWML in Manassas, Va. Analytical techniques used by the laboratories for the waterquality constituents of interest are described in table 4 .

Table 4. Analytical methodologies of the U.S. Geological Survey National Water-Quality Laboratory and Occoquan Watershed Monitoring Laboratory, 1985-96

[All detection limits are in milligrams per liter; OWML, Occoquan Watershed Monitoring Laboratory; USGS NWQL, U.S. Geological Survey National Water-Quality Laboratory; -, not available]

\begin{tabular}{|c|c|c|c|c|}
\hline Constituent & Laboratory & Methodology & Reference & Detection limit \\
\hline Total nitrogen & - & $\begin{array}{l}\text { Sum of total Kjeldahl and } \\
\text { nitrite plus nitrate, dissolved }\end{array}$ & - & 0.20 \\
\hline \multirow[t]{3}{*}{ Total Kjeldahl nitrogen } & OWML & Block digest, colorimetry & Technicon $786-86 \mathrm{~T}^{\mathrm{a}}$ & .04 \\
\hline & USGS NWQL & Block digest, colorimetry & Fishman and Friedman $\mathrm{I}-4552-98^{\mathrm{b}}$ & .20 \\
\hline & & Jirka digest, colorimetry & Fishman and Friedman $1-4515-9]^{b}$ & .20 \\
\hline \multirow[t]{2}{*}{ Nitrite plus nitrate } & OWML & Colorimetry, hydrazine & Technicon $782-86 \mathrm{~T}^{\mathrm{a}}$ & .01 \\
\hline & USGS NWQL & Colorimetry, cd-reduction & Fishman and Friedman $\mathrm{I}-2545-8 \mathrm{I}^{\mathrm{b}}$ & .05 \\
\hline \multirow{3}{*}{$\begin{array}{l}\text { Total phosphorus and } \\
\text { total dissolved phosphorus }\end{array}$} & OWML & Block digest, colorimetry & Technicon $787-86 \mathrm{~T}(1987)^{\mathrm{a}}$ & .01 \\
\hline & USGS NWQL & Block digest, colorimetry & Fishman and Friedman $[-4600-8]^{b}$ & .01 \\
\hline & & Jirka digest, colorimetry & Fishman and Friedman I-4610-91 b & \\
\hline Ortho-phosphorus' & OWML & Colorimetry, auto & Technicon 781-86T (1979) ${ }^{a}$ & .001 \\
\hline Suspended sediment & USGS NWQL & Colorimetry, auto & Fishman and Friedman I-2610-90 $(1985)^{\text {tb }}$ & .001 \\
\hline
\end{tabular}

a. U.S. Environmental Protection Agency, 1979.

b. Fishman and Friedman, 1989. 


\section{Estimation of Loads}

A 7-parameter log-linear regression model (Cohn and others, 1992) was used to characterize concentration data, calculate monthly and annual (calendar year) nutrient and suspended-sediment loads, and estimate trends in concentration data at the four river monitoring stations. The minimumvariance unbiased estimator (MVUE) of Bradu and Mundlak (1970) was used to correct for retransformation bias associated with log-linear regression. The adjusted maximum likelihood estimator (AMLE) (Cohn, 1988) was used to assign concentration values to censored data, which are data reported as less than the analytical detection limit. Statistical aspects of the MVUE are discussed in Cohn and others (1989) and Gilroy and others (1990).

The load-estimation procedure involves two steps-model fitting and load estimation. A linear model is fit by ordinary least squares to the logarithms of the concentration data:

$$
\begin{aligned}
\ln [C]= & \beta_{0^{+}} \beta_{1} \ln \left(Q^{\prime} \bar{Q}\right)+\beta_{2}\left[\ln \left(Q^{\prime} \bar{Q}\right)\right]^{2}+\beta_{3}(T-\bar{T})+ \\
& \beta_{4}(T-\bar{T})^{2}+\beta_{5} \sin (2 \pi T)+\beta_{6} \cos (2 \pi T)+\varepsilon
\end{aligned}
$$

where

$$
\begin{aligned}
& \ln [.]=\text { natural logarithm function; } \\
& C=\text { constituent concentration in milligrams } \\
& \text { per liter }(\mathrm{mg} / \mathrm{L}) \text {; } \\
& \beta \text { 's = model coefficients; } \\
& Q=\text { mean-daily streamflow in cubic feet per } \\
& \text { second }\left(\mathrm{ft}^{3} / \mathrm{s}\right) \text {; } \\
& \bar{Q} \quad=\quad \text { centered streamflow; } \\
& T=\text { time measured in years to two decimal } \\
& \text { points; } \\
& \bar{T} \quad=\quad \text { centered time; } \\
& \sin =\text { sine function; } \\
& \cos =\text { cosine function; and } \\
& \varepsilon=\text { independent, random error. }
\end{aligned}
$$

The above model (equation 1) requires estimation of seven parameters: $\beta_{0}$ is a constant; $\beta_{1}$ and $\beta_{2}$ describe the relation between concentration and discharge; $\beta_{3}$ and $\beta_{4}$ describe trend in concentration data; and $\beta_{5}$ and $\beta_{6}$ describe seasonal variability in concentration data. The error, denoted $\varepsilon$, is assumed to be independent and normally distributed with zero mean and variance. $\bar{Q}$ and $\bar{T}$ are "centering" variables that simplify the numerical work and have no effect on the load estimates (Cohn and others, 1992). They are defined so that the predictor variables corresponding to $\beta_{1}$ and $\beta_{2}$, and $\beta_{3}$ and $\beta_{4}$, respectively, are orthogonal (Cohn and others, 1992).

Daily load estimates are then computed using the MVUE, and averaged to provide monthly and annual mean-daily load estimates in pounds per day. The standard errors of these estimates are computed using formulas discussed in Gilroy and others (1990) and Cohn and others (1992). The standard error of the regression model indicates how close the estimated regression model is to the "true" regression model. The standard error of prediction (SEP) is based on a comparison of "true" load values-measured concentrations multiplied by daily streamflow-against predicted load values; the SEP is a measure of the ability of the model to predict the true load.

Model output describing the parameters from the multivariate log-linear regression (equation 1) is examined to determine which of the parameters is significant in describing the concentration data. A parameter is considered significant if the absolute value of the beta coefficient's $T$-statistic is greater than 2.0 , and its $p$-value is less than or equal to 0.05 . The magnitude and direction [indicated by either a positive (+) or a negative (-) beta coefficient] of the significant parameters is used to describe concentration data.

Model results and regression diagnostics are used to evaluate the validity of the model and characterize the concentration data in terms of their relation to streamflow (table 5), time (table 6), and seasonality. Determining the relation of concentration data to streamflow is important because some water-quality constituents, such as total phosphorus and suspended sediment, can enter a stream primarily from surface runoff, resulting in an increase in concentrations during storm events. In contrast, some constituents, such as nitrate, may be present in highest concentrations during base-flow conditions and become diluted during storm events. Determining a change in concentration levels that occurred over time is important because reductions or increases in concentration levels, may indicate a water-quality response to land-use changes and/or nutrientreduction strategies implemented within the river basin.

Determining seasonal fluctuations in concentrations of nutrients is important in understanding the ecosystems of the Chesapeake Bay. 
Table 5. Interpretation of variability in concentration data due to variations in streamflow

$\left[\beta_{1}\right.$, coefficient of the regression parameter $\ln (Q / \bar{Q}) ; \beta_{2}$, coefficient of the regression parameter $[\ln (Q / \bar{Q})]^{2}$;

In, natural $\log ;[C]$, concentration; $Q$, streamflow; NS, not significant at $p>0.05]$

\begin{tabular}{|c|c|c|}
\hline \multicolumn{2}{|c|}{ Significance and direction of coefficient } & \multirow{2}{*}{ Relation of concentration $(\ln [C])$ to streamflow } \\
\hline$\beta_{1}$ & $\beta_{2}$ & \\
\hline Significant and positive & NS & Concentration increased linearly with increasing streamflow. \\
\hline Significant and negative & NS & Concentration decreased linearly with increasing streamflow. \\
\hline Significant and positive & Significant and positive & $\begin{array}{l}\text { Concentration increased with increasing streamflow and the rate of change } \\
\text { in concentration increased at higher flows. }\end{array}$ \\
\hline Significant and positive & Significant and negative & $\begin{array}{l}\text { Concentration increased with increasing streamflow and the rate of change } \\
\text { in concentration decreased at higher flows. }\end{array}$ \\
\hline NS & Significant and positive & $\begin{array}{l}\text { No significant relation with most streamflow conditions but increased at } \\
\text { higher streamflow. }\end{array}$ \\
\hline NS & Significant and negative & $\begin{array}{l}\text { No significant relation with most streamflow conditions but became diluted } \\
\text { at higher streamflow. }\end{array}$ \\
\hline Significant and negative & Significant and negative & $\begin{array}{l}\text { Concentration decreased with increasing streamflow and the rate of change } \\
\text { in concentration increased at higher streamflow. }\end{array}$ \\
\hline Significant and negative & Significant and positive & $\begin{array}{l}\text { Concentration decreased with increasing streamflow and the rate of change } \\
\text { in concentration decreased at higher flow. }\end{array}$ \\
\hline NS & NS & There is no significant relation between concentration and streamflow. \\
\hline
\end{tabular}

Nutrient levels influence plant growth; plants use up more nutrients in the spring and summer. Concentrations of nutrients increase in the rivers during the winter and spring when the land is most susceptible to erosion and runoff because less vegetative ground cover is available and farmlands have been freshly plowed. The seasonal parameters $\beta_{5}$ and $\beta_{6}$ can be converted into an amplitude and peak day (Helsel and Hirsch, 1992). If either $\beta_{5}$ or $\beta_{6}$ are significant terms in the regression model, then concentrations vary seasonally.

Graphs of residuals from multivariate regression (MR) are used to illustrate the streamflow, time, and seasonal patterns in concentration data identified by the 7-parameter model. Residuals are calculated as the measured value minus the predicted value. MR residual graphs are used because they remove variability from the data and allow for clear illustration of the relation of constituent concentration to streamflow, season, and time.

The first step in the use of MR residual graphs is to regress concentration data against two of the three types of parameters (streamflow, time, and season). This removes variability in the concentration data caused by the two selected parameter types. Next, residuals from the regression are plotted against the remaining third parameter type. A definitive pattern in the residual plot is an indication that concentration data could be further explained by the third parameter type. The final step is to analyze the shape, slope, and direction of the pattern shown in the residuals and 


\section{Table 6. Interpretation of variability in concentration data over time}

$\left[\beta_{3}\right.$, coefficient of the regression parameter $(T-\bar{T}) ; \beta_{4}$, coefficient of the regression parameter $(T-\bar{T})^{2}$;

$T$, time; In, natural log; $[C]$, concentration; NS, not significant, at $p>0.05]$

\begin{tabular}{|c|c|c|}
\hline \multicolumn{2}{|c|}{ Significance and direction of coefficient } & \multirow{2}{*}{ Relation of concentration $(\ln [C])$ to time } \\
\hline$\beta_{3}$ & $\beta_{4}$ & \\
\hline Significant and positive & NS & Concentration increased linearly over time. \\
\hline Significant and negative & NS & Concentration decreased linearly over time. \\
\hline Significant and positive & Significant and positive & $\begin{array}{l}\text { Concentration increased over time, and the rate of increase was accelerated in } \\
\text { later years. }\end{array}$ \\
\hline Significant and positive & Significant and negative & $\begin{array}{l}\text { Concentration increased over time, but the rate of increase slowed down in } \\
\text { later years. }\end{array}$ \\
\hline NS & Significant and positive & Concentration decreased in early years, but increased in later years. \\
\hline NS & Significant and negative & Concentration increased in early years, but decreased in later years. \\
\hline Significant and negative & Significant and negative & $\begin{array}{l}\text { Concentration decreased over time, and the rate of decrease was accelerated in } \\
\text { later years. }\end{array}$ \\
\hline Significant and negative & Significant and positive & $\begin{array}{l}\text { Concentration decreased over time, and the rate of decrease slowed down in } \\
\text { later years. }\end{array}$ \\
\hline NS & NS & There is no significant trend in concentration over time. \\
\hline
\end{tabular}

relate it to the corresponding parameter value (s) in the 7-parameter model.

The following discussion demonstrates how model coefficients, diagnostics, and residual plots are used to characterize concentration data. Equation 2 shows an example using nitrite-plusnitrate concentrations from Potomac River at Washington, D.C., for the period 1985-96. Significant coefficients for this example are shown in bold.

$$
\begin{aligned}
& \ln [C]=0.5610+0.1629 \ln (Q / \bar{Q})-0.1105[\ln (Q / \bar{Q})]^{2}+ \\
& 0.0445(T-\bar{T})-0.0092(T-\bar{T})^{2}- \\
& 0.0876 \sin (2 \pi T)+0.2413 \cos (2 \pi T)+\varepsilon
\end{aligned}
$$

where

$$
\begin{aligned}
& \ln [.]=\text { natural logarithm function; } \\
& C=\text { constituent concentration in milligrams } \\
& \text { per liter }(\mathrm{mg} / \mathrm{L}) \text {; } \\
& \beta \text { 's = model coefficients; } \\
& Q \quad=\text { mean-daily streamflow in cubic feet } \\
& \text { per second }\left(\mathrm{ft}^{3} / \mathrm{s}\right) \text {; } \\
& \bar{Q} \quad=\quad \text { centered streamflow; } \\
& T=\text { time measured in years to two decimal } \\
& \text { points; } \\
& \bar{T} \quad=\text { centered time; } \\
& \sin =\text { sine function; } \\
& \cos =\text { cosine function; and } \\
& \varepsilon=\text { independent, random error. }
\end{aligned}
$$


Model results for equation 2 indicate that the coefficient of the linear-streamflow parameter $(+0.1629)$ was significant. The coefficient of the quadratic-streamflow parameter $(-0.1105)$ is also significant. Collectively, these results indicate that the concentration of nitrite plus nitrate increased with increasing flow at the Potomac River monitoring station, but the rate of change in concentration decreased at higher flows. In addition, the residuals from the regression of concentration against the time and season parameters were plotted against streamflow (fig. $3 a$ ). The pattern in the residuals indicates that a relation exists between concentration and streamflow, which is removed when the streamflow parameters are included in the regression. The residual pattern indicates that the concentrations of nitrite plus nitrate increased with increasing flow at the Potomac River, and that during extreme high-flow conditions, the relation of concentration to flow became nonlinear. The pattern shown in the residuals illustrates the relation described by the streamflow-parameter coefficients $\left(\beta_{1}\right.$ and $\left.\beta_{2}\right)$ in the 7-parameter model for the Potomac River (equation 2).

Model results further indicate that the coefficient of the linear time-trend parameter was positive and significant. This indicates that the concentration of nitrite plus nitrate increased linearly over time, independent of streamflow and season. Near the end of the study period, the rate of increase was diminishing. The residual pattern shown in figure $3 \mathrm{~b}$ shows that the time parameters are important to include in the model and illustrates the relation described by the beta coefficients of the time parameters $\left(\beta_{3}\right.$ and $\left.\beta_{4}\right)$ in the 7-parameter model.

The cosine seasonal parameter is significant. This indicates a seasonal pattern in concentrations of nitrite plus nitrate at the Potomac River. The pattern in residuals shown in figure $3 \mathrm{c}$ indicates that concentrations were lowest in the spring, and that it is necessary to include seasonal parameters in the model to explain that variability. The residual pattern illustrates the relation described by the season-parameter coefficients $\left(\beta_{5}\right.$ and $\left.\beta_{6}\right)$ in the 7-parameter model.

To ensure that the variability in concentration data at the Potomac River monitoring site was adequately described by the model, an additional residual plot was analyzed. Figure 4 shows residuals plotted against predicted concentration values after regressing concentration against all seven parameters in the model (equation 1). Because no clear pattern of residuals emerged, and the majority of the residuals were homogeneously distributed around the zero line, concentration of nitrite-plus-nitrate data at the Potomac River are considered to be well described using the streamflow, season, and time variables.

\section{Calculation of Yields}

Annual yields were calculated in order to make meaningful comparisons of the estimated loads of nutrients and suspended sediment at the four monitoring stations. Annual yields are annual loads that are normalized by the area of the respective river basin (yield equals load divided by the area of basin). The basin area is a major factor in determining the amount of rainfall that is captured within a basin, and thus the amount of ground-water recharge and surface runoff, and, consequently, streamflow; therefore, differences in annual load among basins can be due in part to basin size. Remaining interbasin differences in loads could be attributable to differences in rainfall volume or to basin characteristics that affect constituent loading, such as land-use practices or geology.

\section{Analysis of Trends}

The calculation of trends, which are overall increases or decreases in flow-adjusted concentration over a specified time period, is one way to determine whether or not nutrient-reduction strategies are working in the Chesapeake Bay watershed. To calculate trend, the beta coefficient of the linear time parameter $\left(\beta_{3}\right)$ from the regression model (equation 1 ) is used in equation 3 to estimate average percent change in concentration data over the time period.

$$
\% \Delta C=100\left\{e^{\beta 3 \Delta t}-1\right\}
$$

where

$$
\begin{aligned}
& \% \Delta \mathrm{C}=\text { percent change in flow-adjusted } \\
& \text { e } \quad=\text { anti-log of the natural } \log \text {; } \\
& \beta_{3}=\text { coefficient of the linear time parameter; }
\end{aligned}
$$



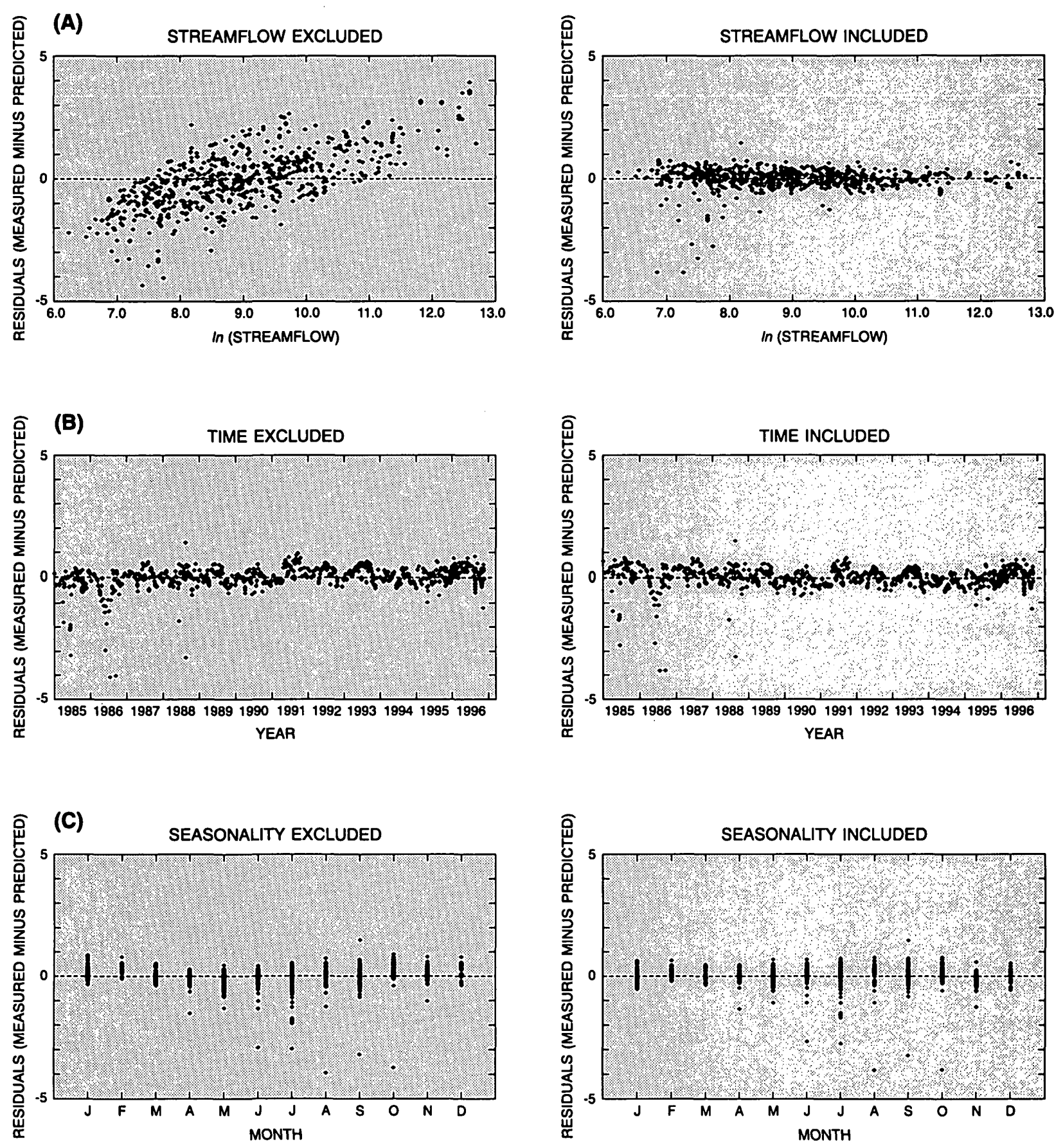

Figure 3. Residuals of regression models for concentrations of nitrite plus nitrate at Potomac River at Washington, D.C., with (A) streamflow, (B) time, and (C) seasonal terms excluded and included as regression parameters. 


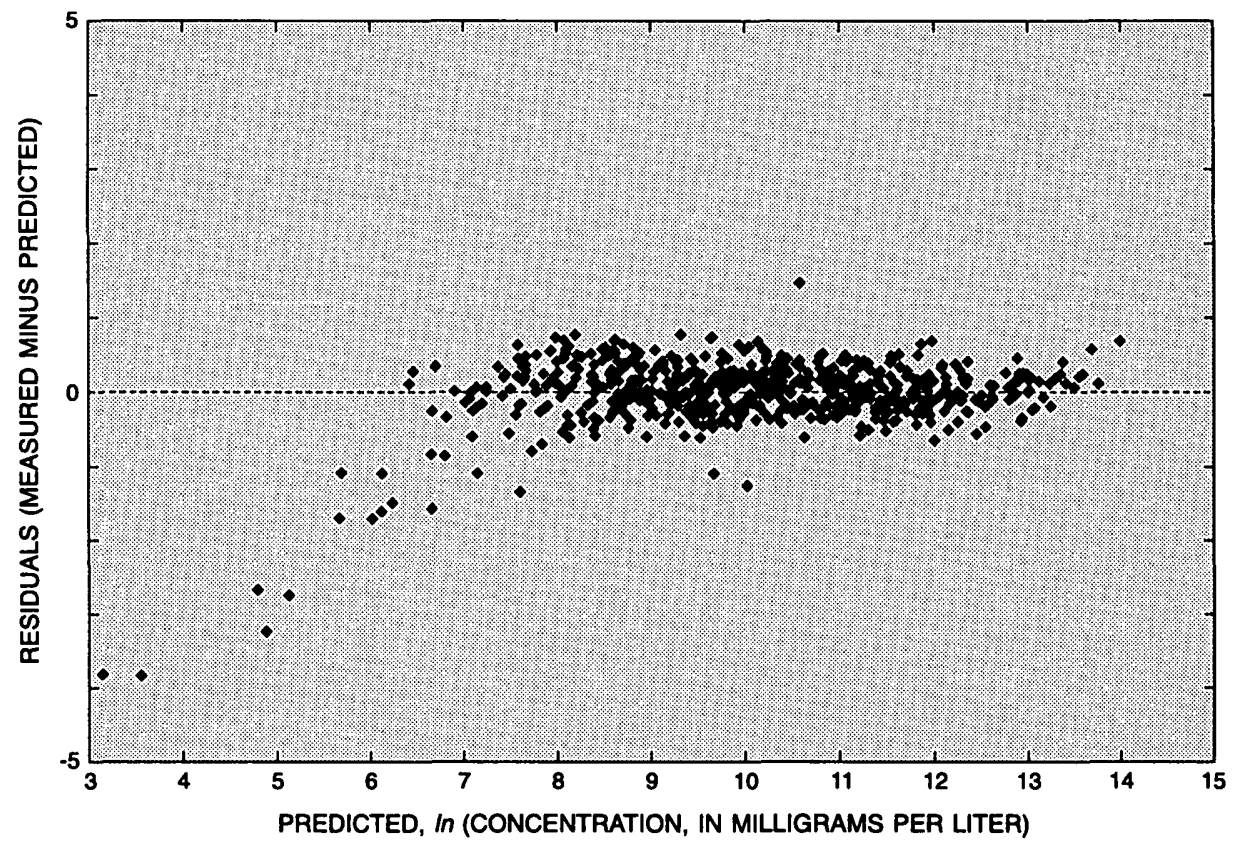

Figure 4. Residuals and model-predicted concentrations of nitrite plus nitrate for the Potomac River at Washington, D.C.

Trend estimated by use of multivariate regression results in this manner is inherently flow-adjusted and seasonally adjusted because each of the model variables are orthogonal (Cohn and others, 1992). A trend was considered significant if the $p$-value for $\beta_{3}$ was less than or equal to 0.05 , which corresponds to a 95 -percent confidence level.

\section{Quality-Assurance Program}

The quality-assurance program included standard processing of field blanks and replicates, as well as documentation of the variability of concentration within the cross section of the river, sediment-transport analysis, comparability of sample-collection techniques among field personnel, and the variability within and among the laboratories where samples were analyzed. The River-Input Monitoring Program's qualityassurance reports are on file at the MarylandDelaware-D.C. District office of the USGS in Baltimore, Md.

In addition, an effort was made to ensure that changes in sample processing procedures and laboratory analysis methods in 1991, 1993, and 1994, did not affect determined concentrations and thus, the trend results for the study. On October 1, 1991, the NWQL modified the method of analysis for Kjeldahl nitrogen and total phosphorus (USGS Internal Memorandum 92.10, 1992). The laboratory converted from the use of the classical "Kjeldahl" method to that of the "Jirka digest" method. This modification enabled the laboratory to halve the volume of sample and reagent used, cut the sample digestion time in half, and analyze the same digest for both total Kjeldahl nitrogen and total phosphorus. On October 1, 1991, the NWQL also instituted the process of blank subtraction for both total Kjeldahl nitrogen and total phosphorus.

Results of analyses of NWQL standard reference samples were evaluated to determine if a bias was present in concentrations of total Kjeldahl nitrogen and total phosphorus reported by NWQL prior to October 1,1991, as a result of changes in analytical methodology. Concentrations of total phosphorus in samples processed prior to October 1, 1991, are biased low, and total Kjeldahl nitrogen data are biased high. Therefore, in the case of trend testing and load estimation, an artificial upward trend in total phosphorus and an artificial downward trend in total Kjeldahl nitrogen (as well as total nitrogen, which is calculated with total Kjeldahl nitrogen) could result. Preliminary testing was performed on 1985-1995 data to determine if the bias was 
statistically significant for concentration levels observed at the River-Input monitoring sites (Gregory Schwarz, USGS, written commun., 1998). Initial results indicated a significant negative bias in concentrations of total Kjeldahl nitrogen at the Potomac River at Chain Bridge station (Darrell and others, in press).

Beginning in November 1993, "ultra-clean" sample-collection methods were used at the RiverInput monitoring stations. The use of sitededicated filtration tubing and sample-collection devices was implemented. Capsule filters replaced the use of $142-\mathrm{mm}$ membrane plate filters. The pore size of the filtration device remained 0.45 microns. A sampling vehicle was purchased in 1993, the interior of which was stripped, cleaned, and rebuilt to meet ultra-clean samplecollection protocol. Samples were filtered and preserved in a designated clean chamber inside the field vehicle to prevent potential atmospheric contamination. On October 1, 1994, nutrient preservative methods were modified. NWQL discontinued the use of mercuric chloride as a nutrient preservative; samples were simply chilled to $4^{\circ}$ Celsius. Quality-assurance tests were conducted before, during, and after implementation of the "ultra-clean" field-method changes. Results showed no significant change in the accuracy of nutrient concentration data collected and analyzed at the four monitoring stations.

\section{Concentrations of Nutrients and Suspended Sediment}

Summary statistics for the concentrations of nutrients and suspended sediment measured from January 1, 1985 through December 31, 1996, at the four monitoring stations are shown in table 7 . These data provide the basis for analysis of concentrations, trends, loads, and yields at the four sites.

The populations of measured concentrations at each site were compared using a nonparametric ANOVA test for multiple sites, also known as a Tukey test. This test determines whether the measured concentration populations are significantly different. Of the four monitored rivers, the Patuxent River had significantly different and the highest median concentrations of all water-quality constituents. This may be due to the location of the monitoring station, which is downstream of eight major sewage-treatment plants. However, stations upstream of the wastewater treatment plants monitored in a different study showed similar concentrations during the study period (Lizárraga, in press). The drainage area of the Patuxent River station also includes the highest total percentage of residential and commercial land (table 1), and has the second highest percentage of agricultural land.

The 7-parameter regression model is used to estimate loads and to describe the variations in concentration data at each station with changes in streamflow, time, and season. The results of each model calibration and the model coefficients are presented in table 8. The data set used for the model calibration, described statistically above, contains an uneven mix of sample types at each of the stations; the data set consists of fixedfrequency samples, single high-flow samples, and multiple samples collected during a single storm. In some cases, duplicate samples, interagency comparison samples, and method-comparison samples are also included in the data sets. As a consequence, some days and short time periods may have a disproportionate influence on the model calibration. The majority of these data, however, are not redundant and are representative of the overall variábility of the system including sampling, analysis, and short-term variability with streamflow. There is currently no technical basis for reducing the high-intensity sample populations and all observations were included in the model, except for composite data collected by OWML at the Potomac River; the 7-parameter model uses discrete values only. One suspended-sediment observation from November 1985 was removed due to its high leverage and influence on the model.

Preliminary tests indicate that thinning the data from high-intensity sample periods does not have a significant effect on the load estimations. The values and significance of the coefficients for the model parameters, however, may be slightly altered. This is most likely if the magnitude of a beta coefficient is low. For example, the model calibration results showed no significant linear trend in total nitrogen at the Potomac River at Washington, D.C., during 1985-96. A 12-percent upward trend in concentrations of total nitrogen was observed, however, when the data set was thinned by using the means of multiple concentrations measured on a single day. This methodology for thinning is not entirely justifiable, however, because it minimizes the true variance of the system and may give false confidence in the coefficients and loads estimated. Future work is 
Table 7. Summary statistics for selected water-quality constituents monitored at the River-Input Monitoring Program stations in Maryland and Washington, D.C., 1985-96 $[<$, less than $]$

\begin{tabular}{|c|c|c|c|c|c|c|c|}
\hline Statistic & $\begin{array}{l}\text { Total } \\
\text { nitrogen }\end{array}$ & $\begin{array}{l}\text { Nitrate } \\
\text { plus } \\
\text { nitrite }\end{array}$ & $\begin{array}{l}\text { Total } \\
\text { Kjeldahl } \\
\text { nitrogen }\end{array}$ & $\begin{array}{l}\text { Total } \\
\text { phosphorus }\end{array}$ & $\begin{array}{l}\text { Total } \\
\text { dissolved } \\
\text { phosphorus }\end{array}$ & $\begin{array}{l}\text { Ortho- } \\
\text { phosphorus }\end{array}$ & $\begin{array}{l}\text { Suspended } \\
\text { sediment }\end{array}$ \\
\hline \multicolumn{8}{|c|}{ Susquehanna River (01578310) } \\
\hline No. & 517 & 548 & 546 & 551 & 549 & 547 & 556 \\
\hline Minimum & 0.82 & 0.16 & $<0.20$ & $<0.01$ & $<0.001$ & $<0.001$ & 1 \\
\hline Mean & 1.84 & 1.27 & .57 & .07 & .020 & .009 & 41 \\
\hline Median & 1.80 & 1.20 & .50 & .05 & .016 & .007 & 18 \\
\hline Maximum & 6.60 & 5 & 3.90 & 1.5 & .142 & .137 & 1,200 \\
\hline \multicolumn{8}{|c|}{ Potomac River (01646580) } \\
\hline No. & 683 & 699 . & 700 & 702 & 660 & 685 & 119 \\
\hline Minimum & 0.35 & $<0.01$ & 0.01 & $<0.010$ & $<0.010$ & $<0.01$ & 3 \\
\hline Mean & 1.95 & 1.34 & .60 & 0.13 & .043 & .03 & 106 \\
\hline Median & 1.80 & 1.31 & .43 & .060 & .030 & .02 & 18 \\
\hline Maximum & 11.0 & 4.50 & 11.0 & 3.29 & .51 & .44 & a 2,990 \\
\hline \multicolumn{8}{|c|}{ Patuxent River (01594440) } \\
\hline No. & 453 & 462 & 461 & 464 & 463 & 459 & 562 \\
\hline Minimum & 1.10 & 0.52 & 0.05 & 0.02 & $<0.01$ & 0.004 & 4 \\
\hline Mean & 3.06 & 2.03 & 1.03 & .228 & .08 & .063 & 84 \\
\hline Median & 2.60 & 1.60 & .90 & .17 & .05 & .040 & 45 \\
\hline Maximum & 8.40 & 6.80 & 3.50 & 1.20 & 1.00 & .880 & 1,110 \\
\hline \multicolumn{8}{|c|}{ Choptank River (01491000) } \\
\hline No. & 324 & 335 & 334 & 335 & 316 & 335 & 420 \\
\hline Minimum & 0.83 & 0.18 & $<0.10$ & $<0.01$ & 0.002 & $<0.001$ & 1 \\
\hline Mean & 1.72 & 1.06 & .66 & .083 & .036 & .024 & 19 \\
\hline Median & 1.70 & 1.00 & .60 & .07 & .030 & .021 & 11 \\
\hline Maximum & 3.60 & 2.00 & 2.80 & .91 & .128 & .095 & 161 \\
\hline
\end{tabular}

${ }^{\text {a. } H i g h-l e v e r a g e ~ d a t a ~ r e m o v e d ~ f r o m ~ d a t a ~ s e t ~ f o r ~ c a l i b r a t i o n ~ o f ~ t h e ~ r e g r e s s i o n ~ m o d e l . ~}$ 


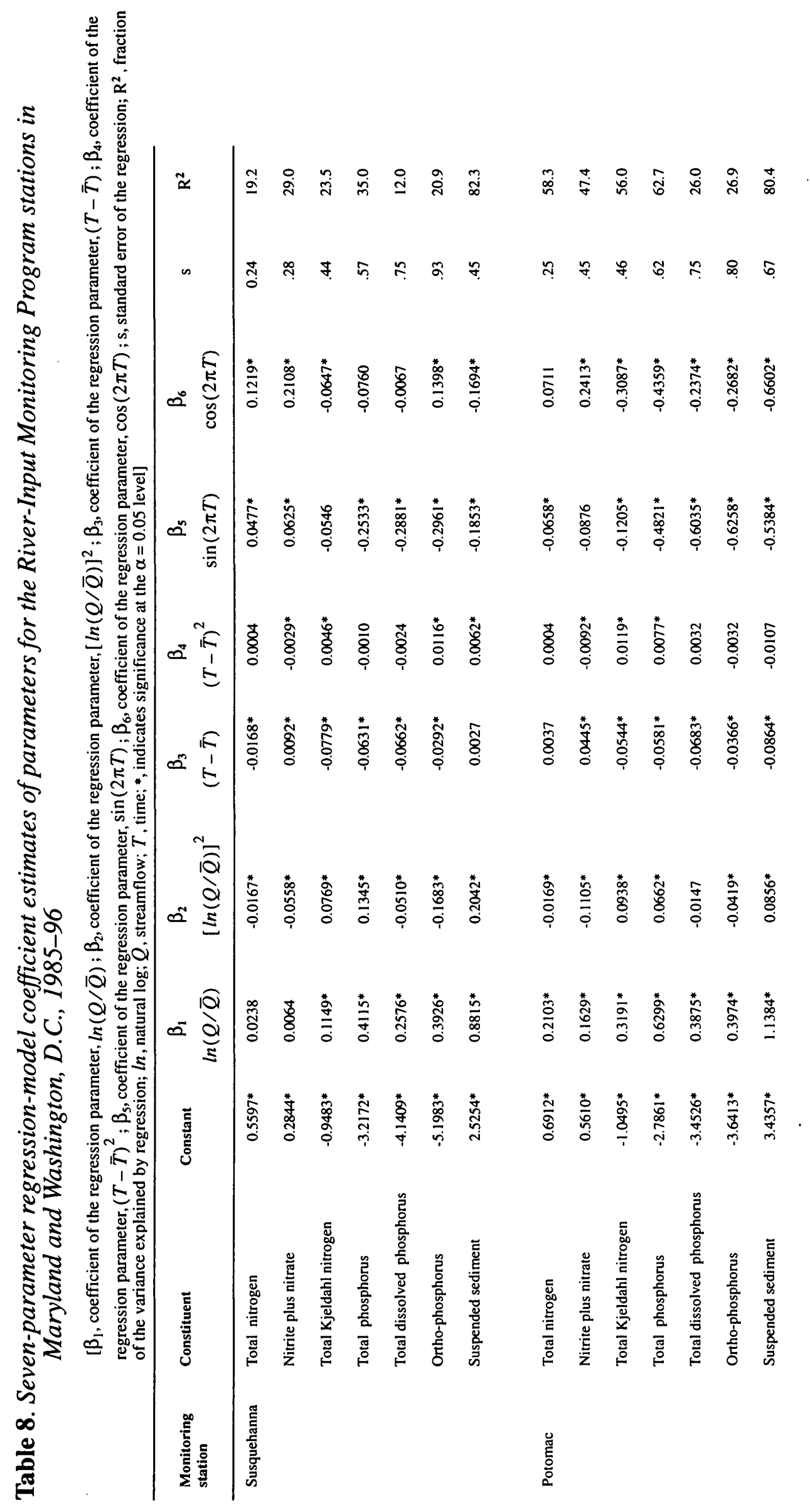




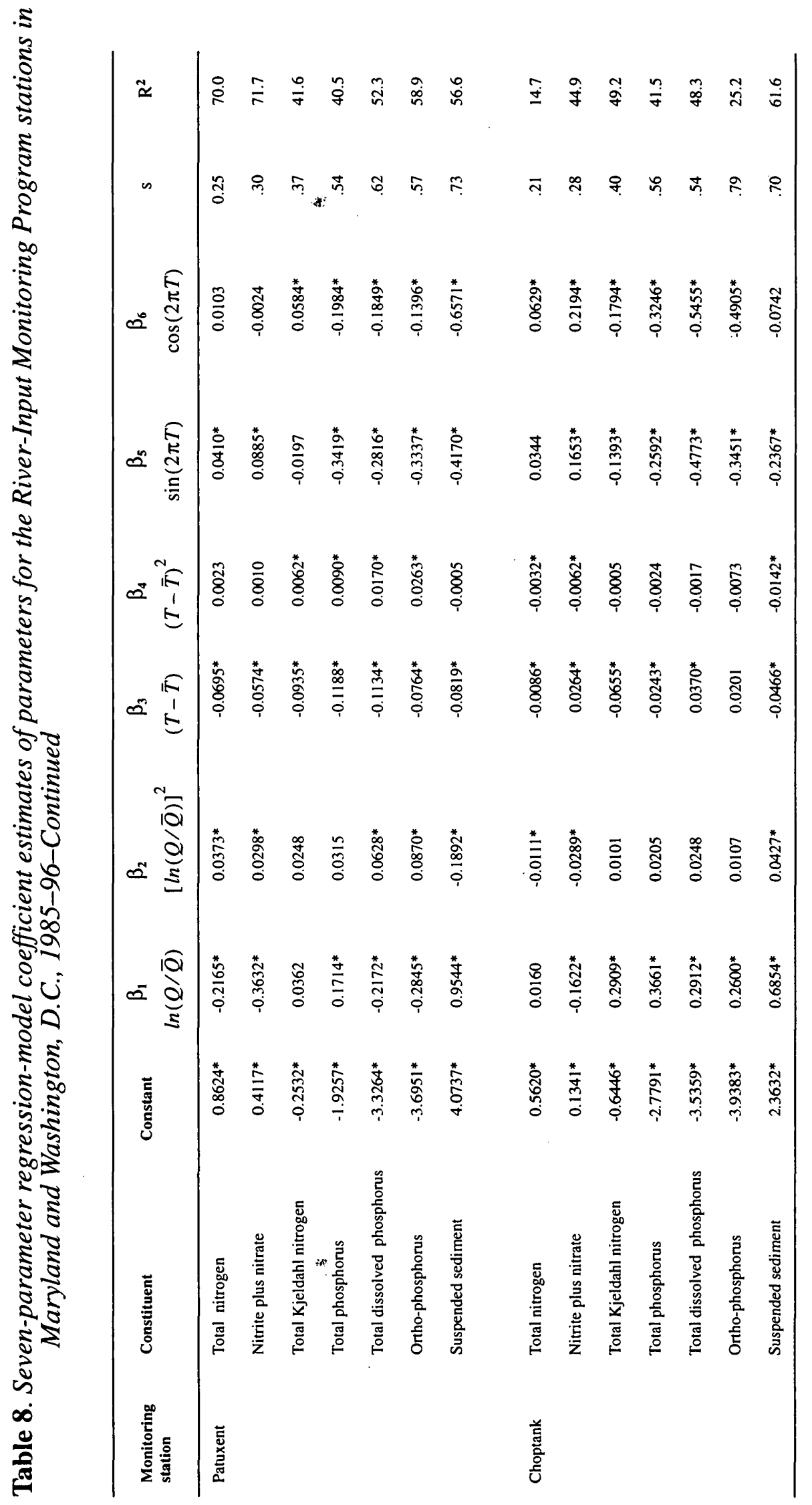


necessary in order the determine the appropriate representation of the data population to include in the calibration data set to achieve the most confidence in the coefficients for the model parameters.

The following sections on each of the rivers describes the range in the concentrations measured at each monitoring station. The results of the 7 -parameter model are listed in table 8 . The streamflow coefficients $\left(\beta_{1}\right.$ and $\left.\beta_{2}\right)$ are used to explain variations in nutrient and suspendedsediment concentrations with respect to streamflow at each monitoring station.

\section{Susquehanna River}

The concentration of total nitrogen at the Susquehanna River monitoring station during 1985-96 ranged from 0.82 to 6.6 milligrams per liter $(\mathrm{mg} / \mathrm{L})$, with a median concentration of $1.8 \mathrm{mg} / \mathrm{L}$. The concentration of total phosphorus ranged from less than $(<) 0.01$ to $1.5 \mathrm{mg} / \mathrm{L}$, with a median concentration of $0.05 \mathrm{mg} / \mathrm{L}$. The concentration of suspended sediment ranged from 1 to $1,200 \mathrm{mg} / \mathrm{L}$, with a median concentration of $18 \mathrm{mg} / \mathrm{L}$.

Concentrations of total Kjeldahl nitrogen, total phosphorus, and suspended sediment increased with increasing streamflow, and the rate of increase in concentration accelerated during extreme high flows. During extreme flows, sediments stored behind Conowingo Dam are scoured; these occurrences may cause these nonlinear increases in particulate concentrations (Gross and others, 1978; Lang, 1982).

\section{Potomac River}

The concentration of total nitrogen at the Potomac River during 1985-96 ranged from 0.35 to $11 \mathrm{mg} / \mathrm{L}$, with a median concentration of $1.8 \mathrm{mg} / \mathrm{L}$. The concentration of total phosphorus ranged from $<0.01$ to $3.3 \mathrm{mg} / \mathrm{L}$, with a median concentration of $0.06 \mathrm{mg} / \mathrm{L}$. The concentration of suspended sediment ranged from 3 to $2,990 \mathrm{mg} / \mathrm{L}$ with a median concentration of $18 \mathrm{mg} / \mathrm{L}$. All of the concentrations of nutrients and suspended sediment increased with increasing streamflow at the Potomac River site.

The rate of increase in concentrations of total Kjeldahl nitrogen, total phosphorus, and suspended sediment also accelerated at higher flows. Because the river channel at the Chain Bridge becomes narrow and deep, the velocity of river flow increases significantly with increasing streamflow. The high velocity causes larger amounts of sediment and associated organic nitrogen and particulate phosphorus to be transported.

\section{Patuxent River}

The concentration of total nitrogen at the Patuxent River during the period 1985-96 ranged from 1.1 to $8.4 \mathrm{mg} / \mathrm{L}$, with a median concentration of $2.6 \mathrm{mg} / \mathrm{L}$. The concentration of total phosphorus ranged from 0.02 to $1.2 \mathrm{mg} / \mathrm{L}$, with a median concentration of $0.17 \mathrm{mg} / \mathrm{L}$. The concentration of suspended sediment ranged from $4 \mathrm{mg} / \mathrm{L}$ to $1,110 \mathrm{mg} / \mathrm{L}$ with a median concentration of $45 \mathrm{mg} / \mathrm{L}$.

In contrast to the larger rivers, concentrations of total nitrogen, nitrite plus nitrate, dissolved phosphorus, and dissolved ortho-phosphorus at the Patuxent River station decreased linearly with increasing streamflow. After an initial dilution, the rate of change in concentrations decreased with higher flows. These results may reflect contributions from point sources upstream; discharges from sewage-treatment plants are often diluted during periods of storm runoff. Concentrations of total phosphorus and suspended sediment increased with increasing streamflow, but unlike the larger sites where scouring may be more significant, the rate of increase in concentration decelerates at higher flows for suspended sediment.

\section{Choptank River}

The concentration of total nitrogen at the Choptank River during 1985-96 ranged from 0.83 to $3.6 \mathrm{mg} / \mathrm{L}$, with a median concentration of $1.7 \mathrm{mg} / \mathrm{L}$. The concentration of total phosphorus ranged from $<0.01$ to $0.91 \mathrm{mg} / \mathrm{L}$, with a median concentration of $0.07 \mathrm{mg} / \mathrm{L}$. The concentration of suspended sediment ranged from 1 to $161 \mathrm{mg} / \mathrm{L}$, with a median concentration of $11 \mathrm{mg} / \mathrm{L}$.

Concentration data for total nitrogen did not vary linearly with streamflow. Concentration data for nitrite plus nitrate decreased with increasing streamflow, and the rate of decrease increased with increasing streamflow. During base-flow conditions, the Choptank River at Greensboro, Md., is dominated by high concentrations of nitrate from ground water. When runoff occurs, concentration of nitrite plus nitrate becomes diluted. In contrast, concentration of total Kjeldahl nitrogen, a particulate form of nitrogen, increased with linearly increasing streamflow. The concentrations of total 
phosphorus, dissolved phosphorus, and dissolved ortho-phosphorus increased linearly with increasing streamflow. The concentration of suspended sediment also increased with increasing streamflow, and the rate of concentration increase accelerated at high flows.

\section{Trends In Concentration Over Time}

Analysis of the 7-parameter regression model results shows a statistically significant reduction in concentrations of most nutrients and suspended sediment at the four river-monitoring stations from 1985-96. The concentration of total nitrogen decreased in all but the Potomac River, concentration of total phosphorus decreased in all of the rivers, and concentration of suspended sediment decreased in all but the Susquehanna River. The flow-adjusted trends in concentrations are shown in figure 5. These downward trends indicate that nutrient and sediment management activities within the contributing watersheds are working and have begun to improve the water quality of the tributaries to the Chesapeake Bay. The last four years of the study period were wet years, however, and the loads during these years were high, masking the downward trends in concentration that the models estimate have been occurring over time.

Many improvements have been made in the municipal and industrial wastewater-treatment facilities within the Chesapeake Bay watershed, and these improvements probably have had a significant effect on the observed trends in flowadjusted concentrations of nutrients. Estimates of nitrogen and phosphorus loadings from point sources upstream of the Susquehanna, Potomac, and Patuxent Rivers in 1985 and 1995 are presented in table 9. The percent reduction was

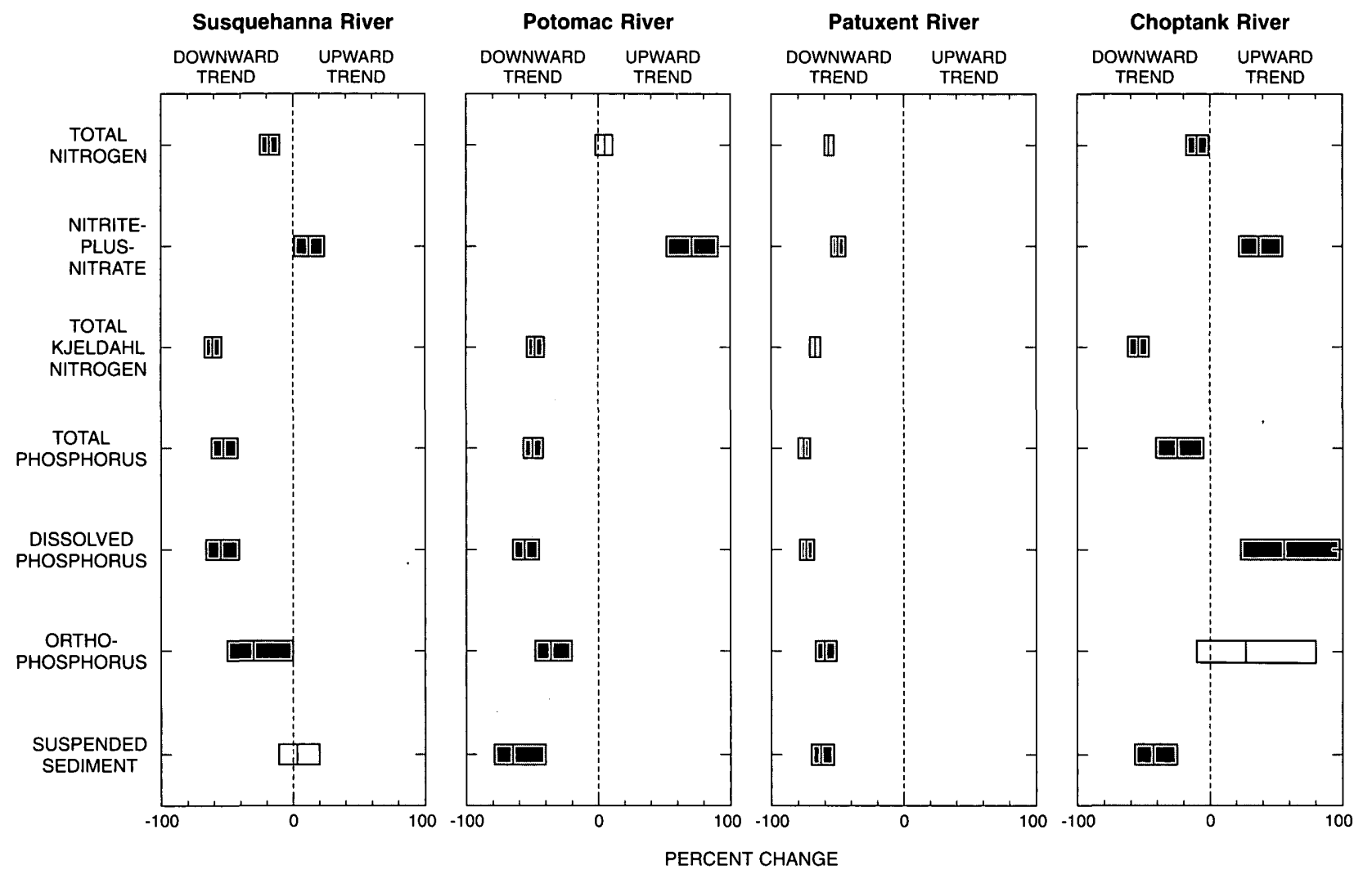

EXPLANATION

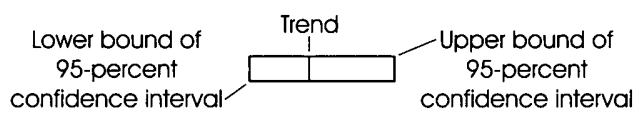

Figure 5. Trends in flow-adjusted concentrations of nutrients and suspended sediment at four river-monitoring stations in the Chesapeake Bay Basin, 1985-96. [Confidence interval is 95 percent. Significant trend, ( $p \leq 0.05)$, is shaded and does not cross the zero (dashed) line.] 
Table 9. Point-source inputs of nitrogen and phosphorus upstream from the Susquehanna, Potomac, and Patuxent River monitoring stations, 1985, 1995, and percent reduction

[Data from Amy Cosgrove, U.S. Environmental Protection Agency, January 1997; all measurements are in million pounds]

\begin{tabular}{|c|c|c|c|c|c|c|}
\hline & \multicolumn{3}{|c|}{ Nitrogen } & \multicolumn{3}{|c|}{ Phosphorus } \\
\hline & 1985 & 1995 & $\begin{array}{l}\text { Reduction } \\
\text { (percent) }\end{array}$ & 1985 & 1995 & $\begin{array}{l}\text { Reduction } \\
\text { (percent) }\end{array}$ \\
\hline Susquehanna River & 66,382 & 48,351 & 27 & 11,548 & 5,075 & 56 \\
\hline Potomac River & 15,552 & 13,928 & 10 & 3,889 & 2,804 & 28 \\
\hline Patuxent River & 3,551 & 1,662 & 53 & 547 & 138 & 75 \\
\hline
\end{tabular}

calculated from the difference between the 1985 and 1995 estimates. No estimates were available for the Choptank River.

There were significant reductions in flowadjusted concentrations of total nitrogen $(-57$ percent), total phosphorus (-76 percent), and suspended sediment (-63) at the Patuxent River monitoring station from 1985-96. Nutrient reductions are probably largely due to improvements at the wastewater-treatment plantsseasonal removal of biological nitrogen was implemented at major sewage-treatment plants in the basin between 1991 and 1993 - and to a phosphate detergent ban which was implemented in the mid-to-late 1980's. Nutrient and sediment management practices have also been implemented in the basin, however, and may be partly responsible for downward trends. The Patuxent River station is the only station where the flow-adjusted concentration of nitrite plus nitrate shows a decrease during this period.

Flow-adjusted concentrations of total Kjeldahl nitrogen decreased significantly at all four monitoring sites, with reductions ranging from -48 to -67 percent. Decreases in flow-adjusted concentration of total nitrogen were of smaller magnitude at the Susquehanna, Potomac, and Choptank Rivers, however, as each of these stations showed significant increases in concentration of nitrite plus nitrate. At the Potomac River station, the reduction in flow- adjusted concentration of total Kjeldahl nitrogen is balanced by an increase in flow-adjusted concentration of nitrite plus nitrate, so that no trend in flow-adjusted total nitrogen is apparent.

Flow-adjusted concentrations of total phosphorus also decreased significantly at all four river-input sites, with reductions ranging from -25 to -76 percent. Flow-adjusted concentrations of dissolved phosphorus and dissolved orthophosphorus also decreased at the Susquehanna, Potomac, and Patuxent Rivers during the period. Flow-adjusted concentration of dissolved phosphorus increased at the Choptank River site, even though flow-adjusted concentration of total phosphorus decreased.

\section{Estimates of Loads of Nutrients and Suspended Sediment}

Loads of nutrients and suspended sediment are highly dependent on streamflow, and the two rivers that had the highest streamflow, the Susquehanna and Potomac, contributed the greatest loads to the Bay. Although the Susquehanna River Basin is larger than the Potomac River Basin, the Potomac River Basin contributed a greater average-annual load of suspended sediment, and a total-phosphorus load that was only slightly smaller than from the Susquehanna River. This is probably due to the trapping of sediments and associated particulate phosphorus behind Conowingo Dam on the Susquehanna River. 
Table 10. Estimated annual loads of nutrients and suspended sediment at the Susquehanna River at Conowingo, Maryland,1985-96

[Standard error of prediction is in parentheses, expressed in percent]

\begin{tabular}{|c|c|c|c|c|c|c|c|}
\hline \multirow[b]{2}{*}{ Year } & \multicolumn{7}{|c|}{ Loads expressed in millions of pounds } \\
\hline & $\begin{array}{l}\text { Total } \\
\text { nitrogen }\end{array}$ & $\begin{array}{l}\text { Nitrite } \\
\text { plus } \\
\text { nitrate }\end{array}$ & $\begin{array}{l}\text { Total } \\
\text { Kjeldahl } \\
\text { nitrogen }\end{array}$ & $\begin{array}{l}\text { Total } \\
\text { phosphorus }\end{array}$ & $\begin{array}{l}\text { Total } \\
\text { dissolved } \\
\text { phosphorus }\end{array}$ & $\begin{array}{l}\text { Ortho- } \\
\text { phosphorus }\end{array}$ & $\begin{array}{l}\text { Suspended } \\
\text { sediment }\end{array}$ \\
\hline 1985 & $125(4)$ & $75.4(4)$ & $46.7(7)$ & $4.11 \quad(9)$ & $1.58(12)$ & $0.82(17)$ & 1,140 \\
\hline 1986 & $165(3)$ & 104 & $59.7(6)$ & $6.31(9)$ & $2.13(10)$ & $0.98(14)$ & $2,480(11)$ \\
\hline 1987 & $125(2)$ & $83.3(3)$ & $39.3(5)$ & 3.85 (7) & $1.49 \quad(8)$ & $0.62(11)$ & 1,170 \\
\hline 1988 & $103(2)$ & 71.9 (3) & $29.7(4)$ & 2.90 & $1.13(8)$ & 0.44 (11) & $852 \quad(8)$ \\
\hline 1989 & $143(2)$ & $99.8(3)$ & $42.6(5)$ & 5.12 & $1.76(8)$ & $0.65(11)$ & 2,050 \\
\hline 1990 & $179(2)$ & $135 \quad(3)$ & $45.2(5)$ & 5.73 & $2.19 \quad(9)$ & $0.90(12)$ & $2,010 \quad(6)$ \\
\hline 1991 & $111(3)$ & 86.4 (3) & $25.2(5)$ & 2.79 & $1.05(10)$ & $0.44(14)$ & 984 (7) \\
\hline 1992 & $125(3)$ & $99.5(3)$ & $27.4(5)$ & $3.03(6)$ & $1.25 \quad(8)$ & $0.54(11)$ & $1,030 \quad(6)$ \\
\hline 1993 & $185(3)$ & $140 \quad(3)$ & $47.7(6)$ & $7.71(10)$ & $1.83(10)$ & $0.82(13)$ & $6,660(10)$ \\
\hline 1994 & $178(3)$ & $137 \quad(3)$ & $41.5(6)$ & 5.84 & $1.65(9)$ & $0.84(12)$ & $4,460 \quad(9)$ \\
\hline 1995 & $96(3)$ & $78.8(4)$ & $18.4(6)$ & $1.93(9)$ & $0.75(11)$ & $0.47(15)$ & $898(8)$ \\
\hline 1996 & $217(4)$ & $169 \quad(5)$ & $47.8(8)$ & $7.16(12)$ & $1.89(13)$ & $1.41(17)$ & $7,560(13)$ \\
\hline $\begin{array}{l}\text { Average-annual } \\
\text { load, } \\
\text { 1985-96 }\end{array}$ & 146 & 107 & 39.3 & 4.71 & 1.56 & 0.74 & 2,610 \\
\hline
\end{tabular}

On average, the load of nitrite plus nitrate comprised a larger percentage of the total nitrogen load measured at the Susquehanna and Potomac River stations than measured at the Patuxent and Choptank River stations. This could be due to the large amount of agricultural land and related nitrate-enriched fertilizer use in the larger river basins.

Annual loads of nutrients and suspended sediment from 1985-96 are listed by station in tables 10-13. The combined annual loads of nitrite plus nitrate and total Kjeldahl nitrogen are approximately equal to the annual load of 
Table 11. Estimated annual loads of nutrients and suspended sediment at the Potomac River at Washington, D.C.,1985-96

[Standard error of prediction is in parentheses, expressed in percent]

\begin{tabular}{|c|c|c|c|c|c|c|c|}
\hline \multirow[b]{2}{*}{ Year } & \multicolumn{7}{|c|}{ Loads expressed in millions of pounds } \\
\hline & $\begin{array}{l}\text { Total } \\
\text { nitrogen }\end{array}$ & $\begin{array}{l}\text { Nitrite } \\
\text { plus } \\
\text { nitrate }\end{array}$ & $\begin{array}{l}\text { Total } \\
\text { Kjeldahl } \\
\text { nitrogen }\end{array}$ & $\begin{array}{l}\text { Total } \\
\text { phosphorus }\end{array}$ & $\begin{array}{l}\text { Total } \\
\text { dissolved } \\
\text { phosphorus }\end{array}$ & $\begin{array}{l}\text { Ortho- } \\
\text { phosphorus }\end{array}$ & $\begin{array}{l}\text { Suspended } \\
\text { sediment }\end{array}$ \\
\hline 1985 & $54.9(5)$ & $25.6(7)$ & $30.6(16)$ & $8.93(31)$ & $2.32(24)$ & $1.19(23)$ & $10,900(57)$ \\
\hline 1986 & $34.6(4)$ & $19.4(6)$ & $12.8(9)$ & $2.12(15)$ & $0.83(13)$ & $0.47(13)$ & $1,340(30)$ \\
\hline 1987 & $50.0(3)$ & $30.3(5)$ & $18.5(9)$ & $3.61(14)$ & $1.28(11)$ & $0.81(11)$ & $3,270(31)$ \\
\hline 1988 & $36.9(4)$ & $23.4(5)$ & $13.9(10)$ & $3.07(17)$ & $0.93(15)$ & $0.62(16)$ & $3,740(32)$ \\
\hline 1989 & $50.6(3)$ & $37.0(5)$ & $15.2(7)$ & $3.34(11)$ & $1.32(10)$ & $0.98(11)$ & $3,160(22)$ \\
\hline 1990 & $44.7(3)$ & $39.4(5)$ & $9.55(6)$ & $2.14(11)$ & $1.05(12)$ & $0.82(13)$ & $1,610(23)$ \\
\hline 1991 & $41.6(3)$ & $35.7(6)$ & $8.50(7)$ & $1.61(12)$ & $0.68(12)$ & $0.52(13)$ & $1,260(22)$ \\
\hline 1992 & $41.7(3)$ & $37.8(5)$ & $8.50(7)$ & $1.67(10)$ & $0.75(10)$ & $0.61(10)$ & $1,160(21)$ \\
\hline 1993 & $84.6(4)$ & $63.0(6)$ & 23.0 & $5.02(12)$ & $1.39(12)$ & $1.08(13)$ & $5,320(22)$ \\
\hline 1994 & $81.7(3)$ & $62.4(5)$ & 20.3 & $4.07(11)$ & $1.21(11)$ & $0.95(11)$ & $3,360(20)$ \\
\hline 1995 & $40.1(3)$ & $36.2(5)$ & $7.93(6)$ & $1.54(10)$ & $0.66(10)$ & $0.53(11)$ & $682(19)$ \\
\hline 1996 & 149 & $103 \quad(5)$ & $48.9(10)$ & 14.4 (19) & $3.20(14)$ & $2.42(14)$ & $12,900(38)$ \\
\hline $\begin{array}{l}\text { Average-annual } \\
\text { load, } \\
\text { 1985-96 }\end{array}$ & 59.2 & 42.8 & 18.1 & 4.29 & 1.30 & 0.92 & 4,060 \\
\hline
\end{tabular}


Table 12. Estimated annual loads of nutrients and suspended sediment at the Patuxent River near Bowie, Maryland,1985-96

[Standard error of prediction is in parentheses, expressed in percent]

\begin{tabular}{|c|c|c|c|c|c|c|c|}
\hline \multirow[b]{2}{*}{ Year } & \multicolumn{7}{|c|}{ Loads expressed in millions of pounds } \\
\hline & $\begin{array}{l}\text { Total } \\
\text { nitrogen }\end{array}$ & $\begin{array}{l}\text { Nitrite } \\
\text { plus } \\
\text { nitrate }\end{array}$ & $\begin{array}{l}\text { Total } \\
\text { Kjeldahl } \\
\text { nitrogen }\end{array}$ & $\begin{array}{l}\text { Total } \\
\text { phosphorus }\end{array}$ & $\begin{array}{l}\text { Total } \\
\text { dissolved } \\
\text { phosphorus }\end{array}$ & $\begin{array}{l}\text { Ortho- } \\
\text { phosphorus }\end{array}$ & $\begin{array}{l}\text { Suspended } \\
\text { sediment }\end{array}$ \\
\hline 1985 & $1.98(4)$ & $1.27(4)$ & $0.74(6)$ & $0.17 \quad(9)$ & $0.071 \quad(9)$ & $0.057(8)$ & $34.2(21)$ \\
\hline 1986 & $1.80(3)$ & $1.19(3)$ & $0.63(5)$ & $0.13(7)$ & $0.051 \quad(7)$ & $0.039(6)$ & $24.3(15)$ \\
\hline 1987 & $2.07(2)$ & $1.34(3)$ & $0.74(4)$ & $0.16 \quad(6)$ & $0.051 \quad(6)$ & $0.036(5)$ & $47.4(14)$ \\
\hline 1988 & $1.98(2)$ & $1.30(3)$ & $0.68(4)$ & $0.13(6)$ & $0.042 \quad(6)$ & $0.028(5)$ & $51.1(13)$ \\
\hline 1989 & $2.56(3)$ & $1.59(3)$ & $0.94(4)$ & $0.22(8)$ & $0.052 \quad(7)$ & $0.034(6)$ & $137.4(15)$ \\
\hline 1990 & $1.98(2)$ & $1.31(3)$ & $0.66(4)$ & $0.13(6)$ & $0.035 \quad(6)$ & $0.024(6)$ & $60.2(12)$ \\
\hline 1991 & $1.45(3)$ & $1.00(3)$ & $0.45(4)$ & $0.076(7)$ & 0.024 & $0.018(6)$ & $25.4(14)$ \\
\hline 1992 & $1.34(3)$ & $0.94(3)$ & $0.40(4)$ & $0.075(7)$ & 0.023 & $0.018(6)$ & $31.5(16)$ \\
\hline 1993 & $1.85(3)$ & $1.20(3)$ & $0.64(4)$ & 0.11 & 0.029 & $0.023(6)$ & $59.0(12)$ \\
\hline 1994 & $1.77(3)$ & $1.16(3)$ & $0.60(4)$ & $0.11 \quad(7)$ & 0.030 & $0.026(6)$ & $54.0(12)$ \\
\hline 1995 & $1.16(3)$ & $0.82(4)$ & $0.35(5)$ & $0.065(8)$ & 0.023 & $0.024(7)$ & $25.5(16)$ \\
\hline 1996 & $2.29(4)$ & $1.41(4)$ & $0.89(6)$ & $0.19 \quad(9)$ & $0.051(10)$ & $0.056(9)$ & $115.4(14)$ \\
\hline $\begin{array}{l}\text { Average-annual } \\
\text { load, } \\
\text { 1985-96 }\end{array}$ & 1.85 & 1.21 & 0.64 & 0.13 & 0.040 & 0.032 & 55.5 \\
\hline
\end{tabular}


Table 13. Estimated annual loads of nutrients and suspended sediment at the Choptank River near Greensboro, Maryland, 1985-96

[Standard error of prediction is in parentheses, expressed in percent]

\begin{tabular}{|c|c|c|c|c|c|c|c|}
\hline \multirow[b]{2}{*}{ Year } & \multicolumn{7}{|c|}{ Loads expressed in millions of pounds } \\
\hline & $\begin{array}{l}\text { Total } \\
\text { nitrogen }\end{array}$ & $\begin{array}{l}\text { Nitrite } \\
\text { plus } \\
\text { nitrate }\end{array}$ & $\begin{array}{l}\text { Total } \\
\text { Kjeldahl } \\
\text { nitrogen }\end{array}$ & $\begin{array}{l}\text { Total } \\
\text { phosphorus }\end{array}$ & $\begin{array}{l}\text { Total } \\
\text { dissolved } \\
\text { phosphorus }\end{array}$ & $\begin{array}{l}\text { Ortho- } \\
\text { phosphorus }\end{array}$ & $\begin{array}{l}\text { Suspended } \\
\text { sediment }\end{array}$ \\
\hline 1985 & $0.23(4)$ & $0.127(5)$ & $0.10 \quad(9)$ & $0.010(14)$ & $0.0035(14)$ & $0.0024(20)$ & $1.77(25)$ \\
\hline 1986 & $0.33(3)$ & $0.18 \quad(4)$ & 0.14 & $0.013(11)$ & $0.0037(10)$ & $0.0029(15)$ & $3.47(20)$ \\
\hline 1987 & $0.36(3)$ & $0.21 \quad(3)$ & $0.15 \quad(6)$ & $0.015(10)$ & $0.0042(8)$ & $0.0035(12)$ & $3.82(16)$ \\
\hline 1988 & $0.27(2)$ & $0.18 \quad(3)$ & $0.093(5)$ & $0.009 \quad(7)$ & $0.0035 \quad(7)$ & $0.0029(10)$ & $1.89(13)$ \\
\hline 1989 & $0.77(2)$ & $0.42 \quad(3)$ & $0.36(5)$ & $0.048 \quad(8)$ & 0.0190 & 0.015 (11) & $11.5 \quad(13)$ \\
\hline 1990 & $0.41(2)$ & $0.27 \quad(3)$ & $0.15 \quad(6)$ & $0.019(10)$ & $0.0075 \quad 10)$ & $0.0061(14)$ & $4.19(18)$ \\
\hline 1991 & $0.36(3)$ & $0.25 \quad(3)$ & 0.11 & $0.014 \quad(8)$ & 0.0062 & $0.0049(12)$ & $2.98(14)$ \\
\hline 1992 & $0.30(2)$ & 0.23 & $0.081(5)$ & $0.010 \quad(7)$ & 0.0052 & $0.0040(11)$ & $1.73(11)$ \\
\hline 1993 & $0.42(3)$ & $0.29 \quad(4)$ & $0.13 \quad(7)$ & 0.018 (11) & 0.0071 & $0.0056(14)$ & $4.49(19)$ \\
\hline 1994 & $0.68(3)$ & $0.43 \quad$ (4) & $0.25 \quad(8)$ & 0.039 (13) & $0.0176(11)$ & 0.012 (16) & $12.2 \quad(26)$ \\
\hline 1995 & $0.31(3)$ & $0.24 \quad(4)$ & $0.074(7)$ & $0.010(10)$ & 0.0055 & $0.0038(13)$ & $1.60(16)$ \\
\hline 1996 & $0.86(4)$ & 0.53 & $0.31 \quad(9)$ & 0.054 (13) & $0.0314(12)$ & $0.018 \quad(18)$ & $10.8 \quad(22)$ \\
\hline $\begin{array}{l}\text { Average-annual } \\
\text { load, } \\
1985-96\end{array}$ & 0.44 & 0.28 & 0.16 & 0.022 & 0.0095 & 0.0067 & 5.04 \\
\hline
\end{tabular}

total nitrogen. The dissolved ortho-phosphorus loads make up most of the dissolved phosphorus loads, which comprise the dissolved part of the total phosphorus loads. Monthly loads of nutrients and suspended sediment for the Susquehanna, Potomac, Patuxent, and Choptank Rivers are plotted for the period 1985-96 in figures 6-9 to show the temporal variability in loading rates. 

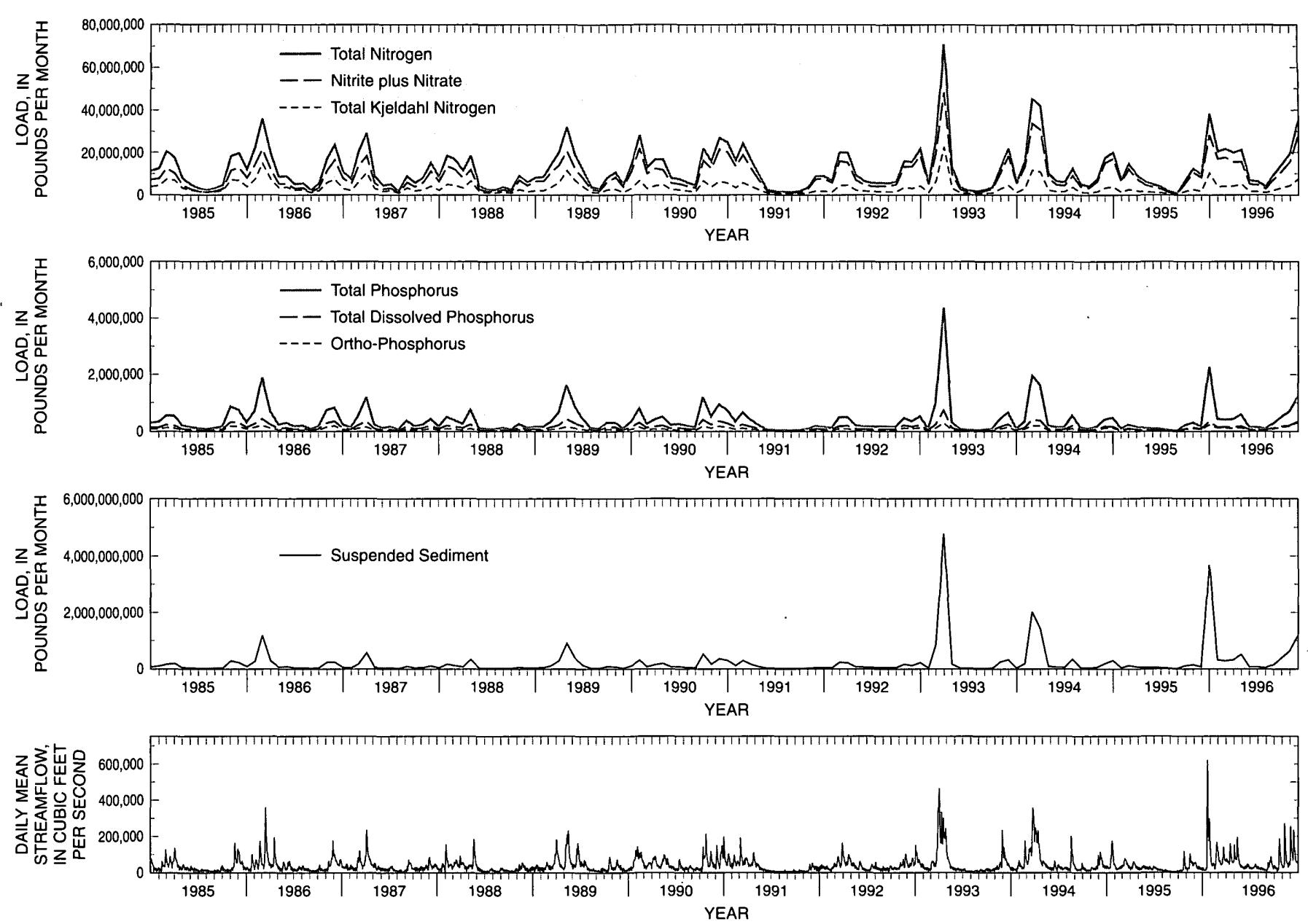

Figure 6. Monthly loads of nutrients and suspended sediment and daily mean streamflow at the Susquehanna River at Conowingo, Md., 1985-96.

\section{Susquehanna River}

The annual load of total nitrogen entering Chesapeake Bay from the nontidal part of the Susquehanna River as measured at Conowingo, Md., ranged from 96 million pounds (in 1995) to 217 million pounds (in 1996), with an average-annual load of 146 million pounds.

Approximately three-quarters of the total nitrogen load transported during the study period was in the form of nitrite plus nitrate. The annual load of total phosphorus ranged from 1.93 million pounds (in 1995) to 7.71 million pounds (in 1993), with an average-annual load of 4.71 million pounds. Approximately one-third of the total phosphorus load transported during the study period was in the dissolved phase, of which about half was dissolved ortho-phosphorus. The annual load of suspended sediment ranged from 852 million pounds (in 1988) to 7.56 billion pounds (in 1996), with an average-annual load of 2.61 billion pounds. 

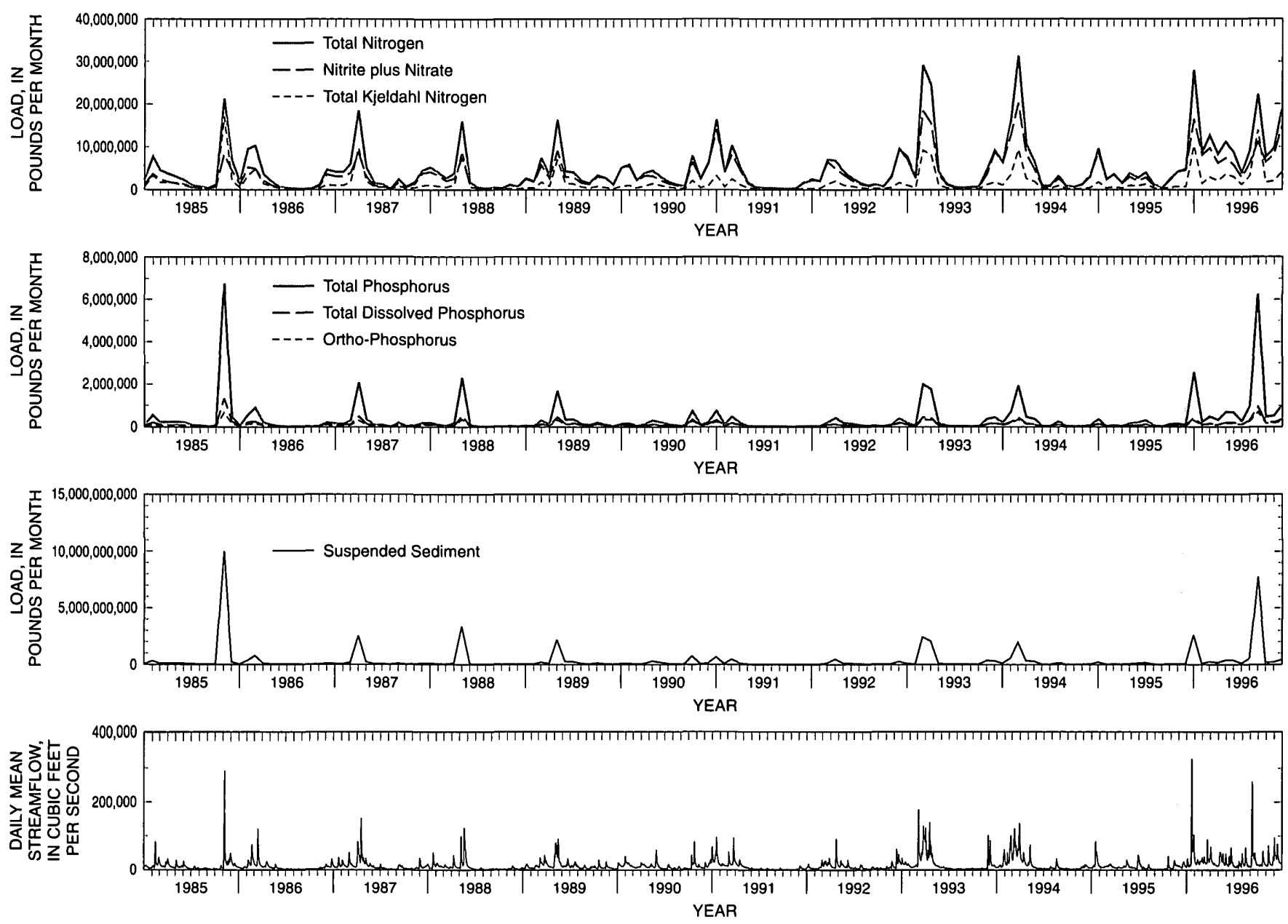

Figure 7. Monthly loads of nutrients and suspended sediment and daily mean streamflow at the Potomac River at Washington, D.C., 1985-96.

\section{Potomac River}

The annual load of total nitrogen entering Chesapeake Bay from the nontidal part of the Potomac River as measured at Washington, D.C., ranged from 34.6 million pounds (in 1986) to 149 million pounds (in 1996), with an averageannual load of 59.2 million pounds. Approximately three-quarters of the total nitrogen load transported during the study period was in the form of nitrite plus nitrate. The annual load of total phosphorus ranged from 1.54 million pounds (in 1995) to 14.4 million pounds (in 1996), with an average-annual load of 4.29 million pounds. Approximately one-third of the total phosphorus load transported during the study period was in the dissolved phase, 70 percent of which was dissolved ortho-phosphorus. The annual load of suspended sediment ranged from 682 million pounds (in 1995) to 12.9 billion pounds (in 1996), with an average-annual load of 4.06 billion pounds. 

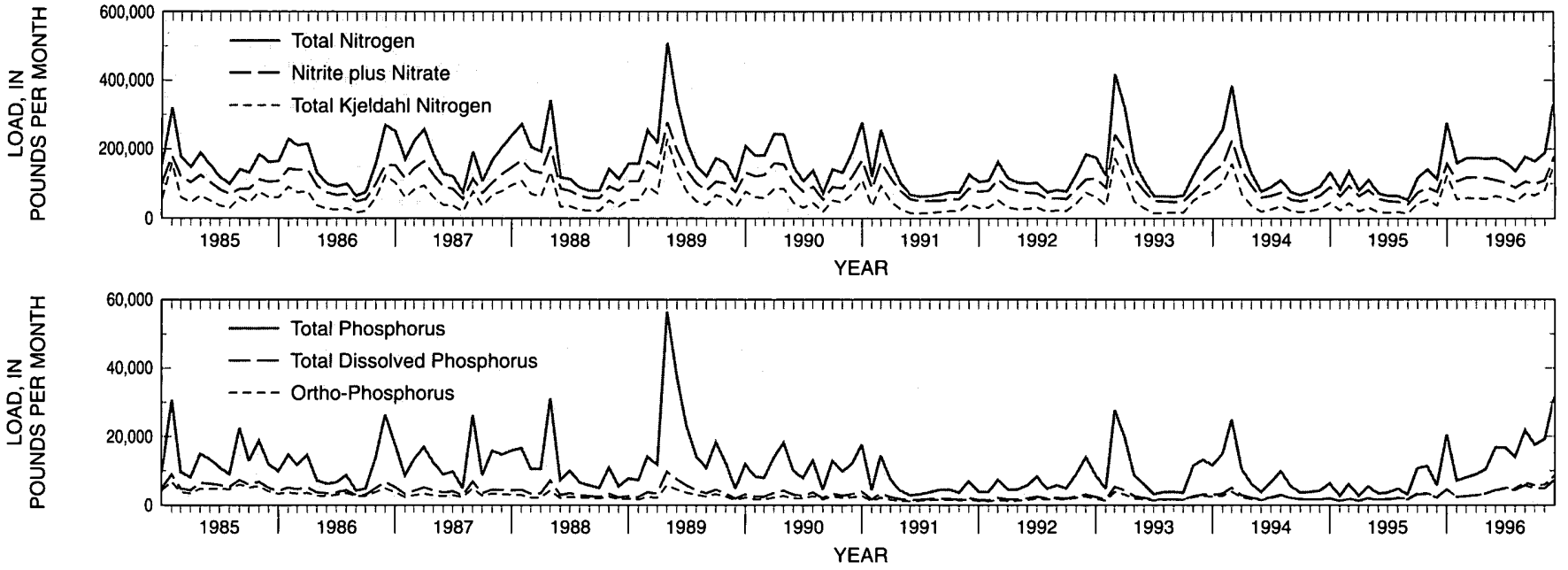

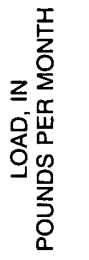
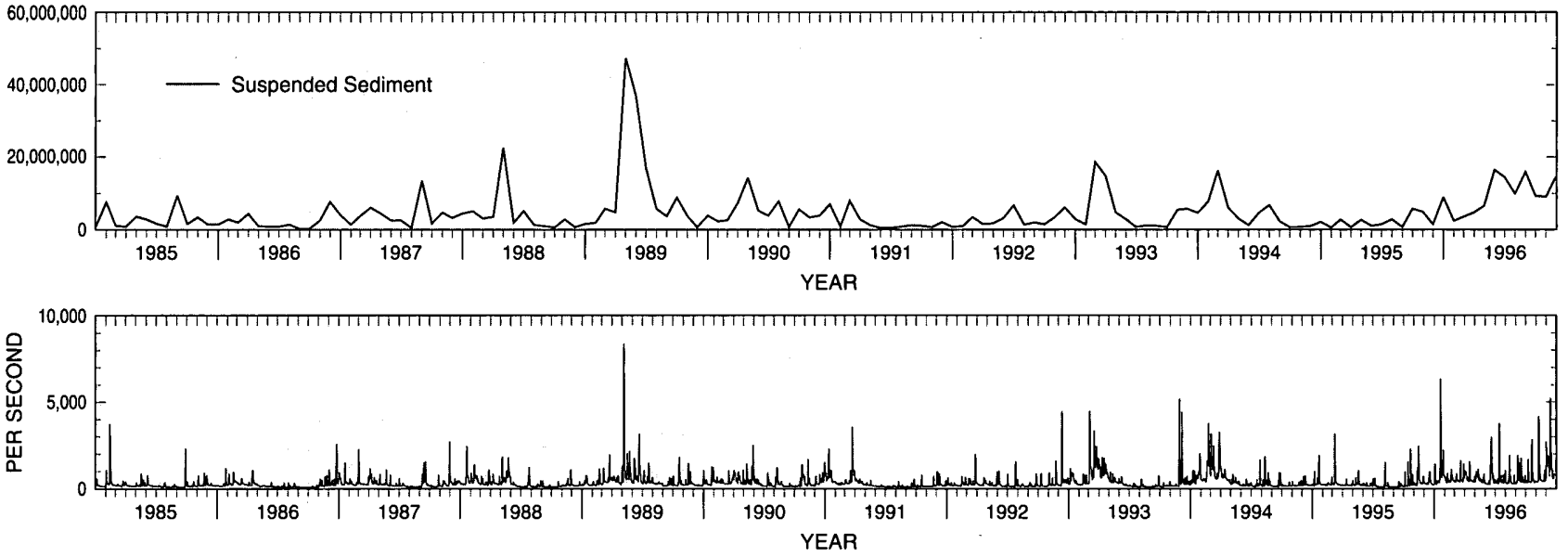

Figure 8. Monthly loads of nutrients and suspended sediment and daily mean streamflow at the Patuxent River near Bowie, Md., 1985-96.

\section{Patuxent River}

The annual load of total nitrogen entering Chesapeake Bay from the nontidal part of the Patuxent River as measured at the monitoring station near Bowie, Md., ranged from 1.16 million pounds (in 1995) to 2.56 million pounds (in 1989), with an averageannual load of 1.85 million pounds. Approximately two-thirds of the total nitrogen load transported during the study period was in the form of nitrite plus nitrate. The annual load of total phosphorus ranged from 65,000 pounds (in 1995 ) to 220,000 pounds (in 1989), with an average-annual load of 130,000 pounds.

Approximately one-third of the total phosphorus load transported during the study period was in the dissolved phase. The annual suspended-sediment load ranged from 24.3 million pounds (in 1986) to 137.4 million pounds (in 1989), with an averageannual load of 55.5 million pounds. 

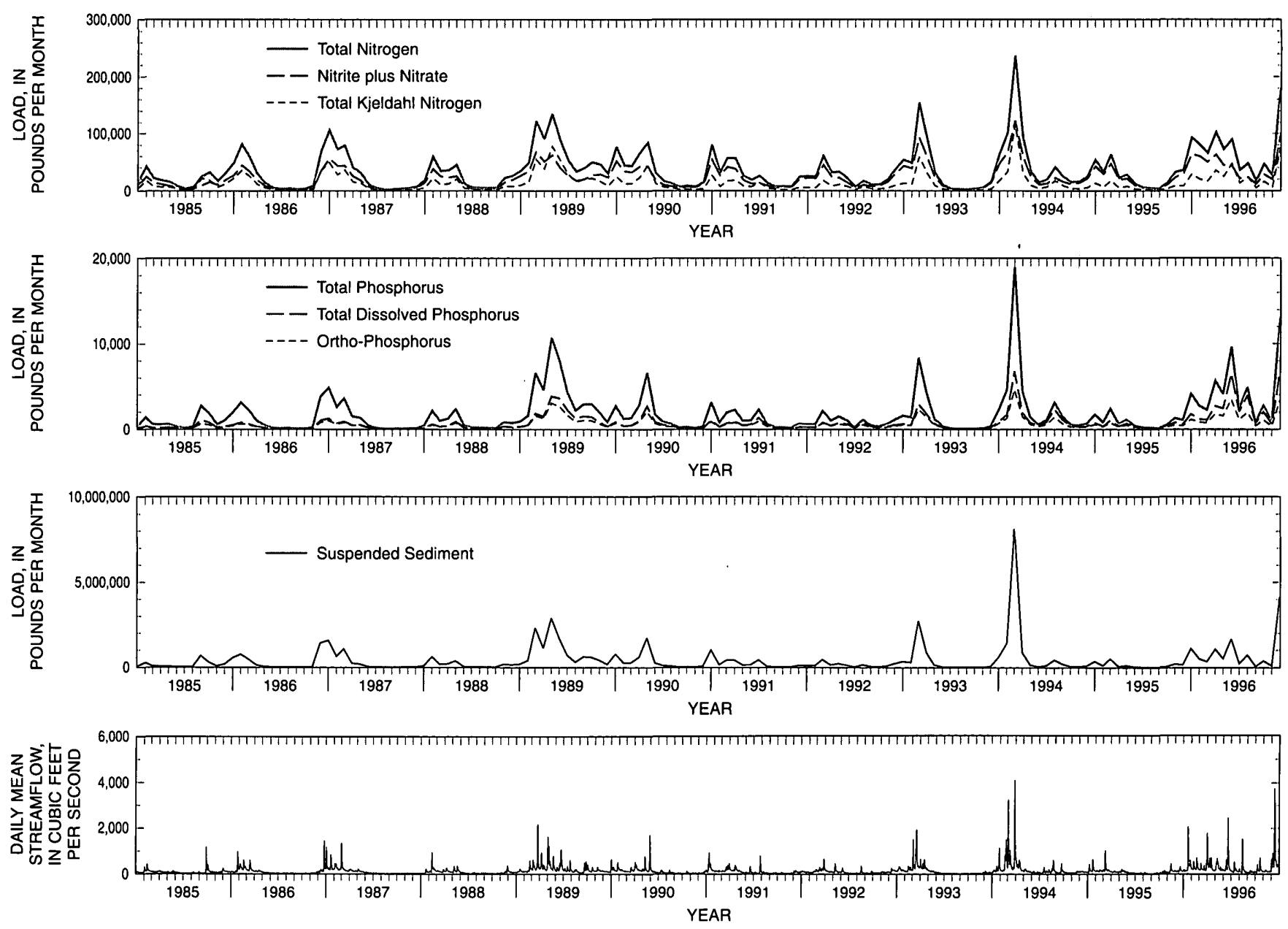

Figure 9. Monthly loads of nutrients and suspended sediment and daily mean streamflow at the Choptank River near Greensboro, Md., 1985-96.

\section{Choptank River}

The annual load of total nitrogen entering Chesapeake Bay from the nontidal part of the Choptank River as measured at the monitoring station near Greensboro, Md., ranged from 230,000 pounds (in 1985) to 860,000 pounds (in 1996), with an average-annual load of 440,000 pounds. Approximately two-thirds of the total nitrogen load transported during the study period was in the form of nitrite plus nitrate. The annual load of total phosphorus ranged from 9,000 pounds (in 1988) to 54,000 pounds (in 1996), with an average-annual load of 22,000 pounds. Approximately 40 percent of the total phosphorus load transported during the study period was in the dissolved phase. The annual load of suspended sediment ranged from 1.60 million pounds (in 1995) to 12.2 million pounds (in 1994), with an averageannual load of 5.04 million pounds. 


\section{Areal Yields of Water, Nutrients, and Suspended Sediment}

The distributions of the annual yields of total nitrogen, nitrite plus nitrate, total phosphorus, and suspended sediment over the study period were determined for the four river monitoring stations (fig. 10). Distribution of annual water yields was also plotted for each station over the study period to determine if there was hydrologic variability not accounted for in the normalization by the basin area. The Susquehanna River Basin shows the highest median-annual water yields during the study period, which was expected; there is more precipitation in the north, typically. The Susquehanna and Patuxent River Basins had the highest median-annual yields of nitrogen during the study period and the Patuxent River Basin also had the highest median-annual yield of total phosphorus. The Potomac River Basin had the highest median-annual yield of suspended sediment during the study period, and extremely high yields of suspended sediment during 1985 and 1996, when there were large storms in the basin.
Median-annual yields of total phosphorus and suspended sediment from the Susquehanna and the Choptank River Basins are lower than from the Potomac and Patuxent River Basins. The relatively small yield of total phosphorus and suspended sediment from the Susquehanna River may be due to the location of the monitoring station below Conowingo Dam. The dam traps approximately 70 percent of the suspended sediment and approximately 45 percent of the total phosphorus carried by the Susquehanna River to Chesapeake Bay (Ott and others, 1991). 

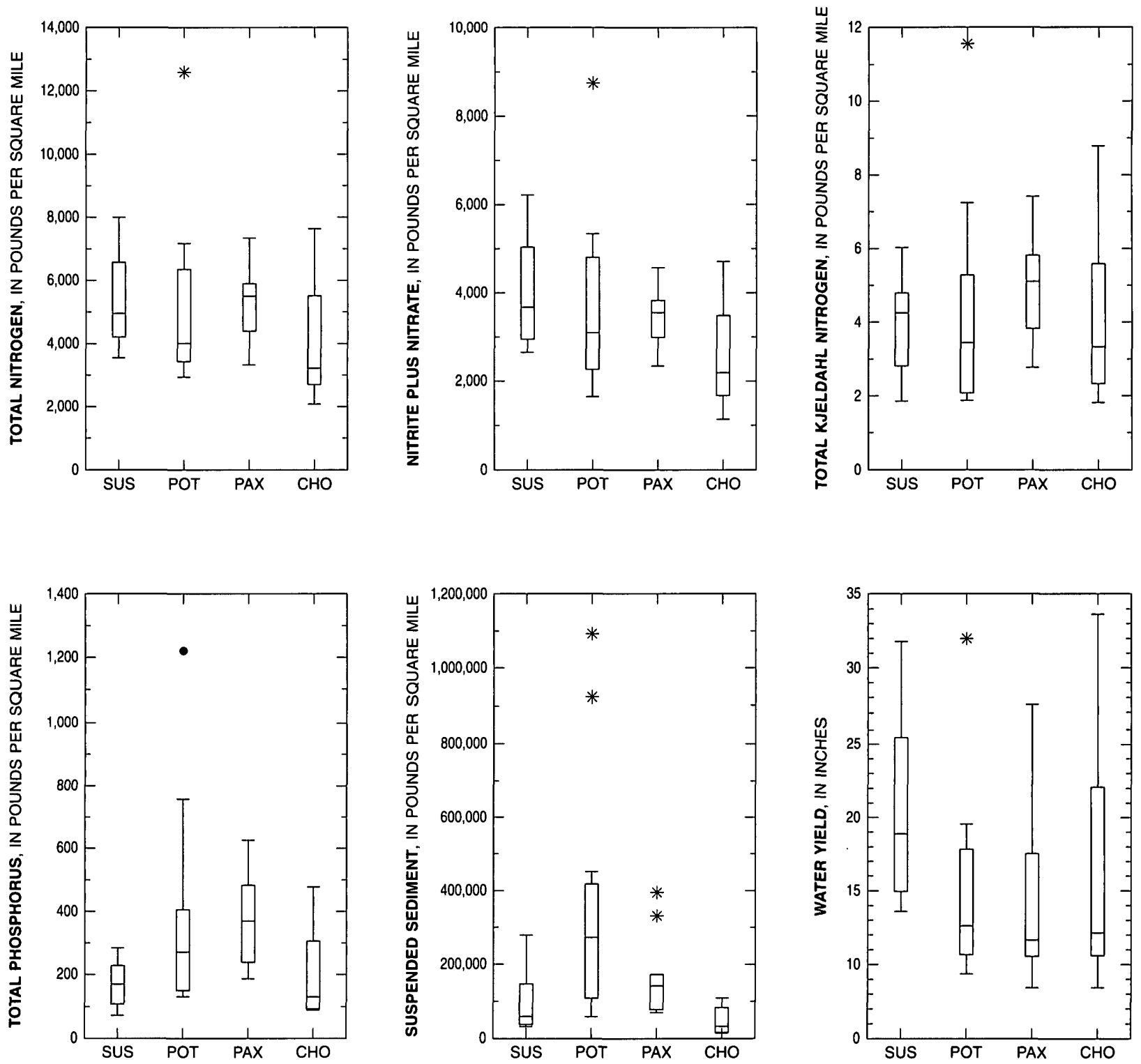

\section{EXPLANATION}

- Outlier data value greater than 3 times the interquartile range outside the quartile

* Outlier data value less than or equal to 3 times and greater than 1.5 times the interquartile range outside the quartile

$\begin{aligned} & \text { Data value less } \\ & \text { the interquartile } \\ & 75 \text { th percentile } \\ & \text { Median } \\ & 25 \text { th percentile }\end{aligned}$

Figure 10. Annual nutrient, suspended-sediment, and water yields from the nontidal parts of the Susquehanna (SUS), Potomac (POT), Patuxent (PAX), and Choptank (CHO) River Basins, 1985-96. 


\section{Summary and Conclusions}

The Chesapeake Bay is the largest and most productive estuary in the Nation. The health and productivity of the Bay are threatened, however, from an overabundance of nutrients (nitrogen and phosphorus) and suspended sediment that enter the estuary from its rivers. In the early-to-mid 1980's, Federal, State, and local governments implemented programs to reduce the nutrients and suspended sediment in rivers discharging to the Bay. In order to quantify improvements in water quality resulting from these efforts, the State of Maryland, in cooperation with the Metropolitan Washington Council of Governments and the U.S. Geological Survey, began the Chesapeake Bay River-Input Monitoring Program.

The monitoring program was established in 1983 to characterize water quality and to quantify loads and long-term trends in nutrients and suspended sediment entering the Chesapeake Bay from the nontidal part of the Susquehanna, Potomac, Patuxent, and Choptank Rivers. These rivers collectively contribute approximately 70 percent of the total streamflow to the Bay, on the basis of data collected from 1951-60. For the purpose of this report, nutrient and sediment data from the River-Input Monitoring Program for 1985-96 were analyzed using statistical regression techniques to determine progress toward achieving improvements in the water quality of tributaries to the Chesapeake Bay.

During the years 1985-92, annual mean-daily streamflow at the four river monitoring stations was at or below the long-term average, with the exception of 1989 , which was a high flow year for the Patuxent and Choptank Rivers, and 1990, which was a high flow year for the

Susquehanna River. During the later years of the study period (1993-96), annual mean-daily flow at the four rivers was above average, with the exception of 1993 at the Choptank River, and 1995, when flow was below average at all four monitoring stations. A 46-year record for total streamflow was set in 1996, largely due to floods in January of that year.
Of the four monitored rivers, the Patuxent River had the highest measured concentrations of all nutrients and suspended sediment. The drainage area for the Patuxent River station includes eight major sewage-treatment plants and includes the highest combined percentage of agricultural, residential, and commercial land of the four basins. At the Susquehanna and Potomac Rivers, concentrations of total Kjeldahl nitrogen, total phosphorus, and suspended sediment increased with increasing streamflow, and the rate of increase accelerated at highest flows. The accelerated rate of increase at the Susquehanna River monitoring station may be due to scour behind Conowingo Dam during streamflows greater than 400,000 cubic feet per second. The accelerated rate of increase at the Potomac River may be due to the increasing velocity of the river through the part of the river upstream from the site as flows increase.

During the study period, there were downward trends in flow-adjusted concentrations of total nitrogen in all but the Potomac River, downward trends in flow-adjusted concentrations of total phosphorus in all four rivers, and downward trends in flow-adjusted concentrations of suspended sediment in all but the Susquehanna River. These results indicate that progress has been made in reducing the concentrations of nutrients and suspended sediment in the rivers, and thus in reducing the amount of load per unit of streamflow that is transported by these rivers to the Bay. During major storms, however, the rivers continue to transport large amounts of nutrients and suspended sediment to Chesapeake Bay.

The loads of nutrients and suspended sediment carried by a river are highly dependent on the volume of flow, and the two rivers that contributed the greatest amount of water to Chesapeake Bay, the Susquehanna and the Potomac, also contributed the greatest amount of nutrient and suspended-sediment load to the Bay. The Susquehanna River transported the highest 
average-annual total phosphorus load (4.71 million pounds per year) and total nitrogen load 146 million pounds per year), whereas the Potomac River transported the highest average-annual suspended-sediment load (4.1 billion pounds per year) to the Bay.

Loads and streamflow were normalized by basin drainage area to account for some of the hydrologic variability caused by basin size. The Susquehanna River Basin showed the highest median-annual water yields during the study period, which would be expected; there is more precipitation in the north. The Susquehanna and Patuxent River Basins had the highest medianannual yields of nitrogen during the study period, and the Patuxent River Basin also had the highest median-annual yield of total phosphorus. The Potomac River Basin had the highest medianannual yield of suspended sediment during the study period.
Total phosphorus and suspended-sediment median-annual yields are lower from the Susquehanna and the Choptank River Basins than from the Potomac and Patuxent River Basins. The relatively small yield of total phosphorus and suspended sediment from the Susquehanna River may be due to the location of the monitoring station below Conowingo Dam. The dam traps approximately 70 percent of the suspended sediment and approximately 45 percent of the total phosphorus carried by the Susquehanna River to Chesapeake Bay. 


\section{Selected References}

American Public Health Association, American Water Works Association, Water Pollution Control Federation, 1980, Standard methods for the examination of water and wastewater, 15th edition: Washington, D.C., 20005.

Bradu, D., and Mundlak, Y., 1970, Estimation of lognormal linear models: Journal of the American Statistical Association, 65 (329), p. 198-211.

Buchanan, T.J., and Somers, W.P., 1982, Stage measurement at gaging stations: U.S. Geological Survey Techniques of WaterResources Investigations, book 3, chap. A7, 28 p.

Bue, C.D., 1968, Monthly surface-water inflow to Chesapeake Bay, Prepared in cooperation with the States of Maryland, Pennsylvania, and Virginia: U.S. Geological Survey Open-File Report, 42 p.

Carter, R.W., and Davidian, J., 1968, General procedure for gaging streams: U.S. Geological Survey Techniques of Water-Resources Investigations, book 3, chap. A6, 13 p.

Cohn, T.A., 1988, Adjusted maximum likelihood estimation of the moments of lognormal populations from type I censored samples: U.S. Geological Survey Open-File Report 88-350, 34 p.

Cohn, T.A., Delong, L.L., Gilroy, E.J., Hirsch, R.M., and Wells, D., 1989, Estimating constituent loads: Water Resources Research, v. 25 , no. 5, p. 937-942.

Cohn, T.A., Caulder, D.L., Gilroy, E.J., Zynjuk, L.D., and Summers, R.M., 1992, The validity of a simple log-linear model for estimating fluvial constituent loads: An empirical study involving nutrient loads entering Chesapeake Bay: Water Resources Research, v. 28, no. 9, p. 2,353-2,364.

Colby, B.R., 1955, The relationship of sediment discharge to streamflow: U.S. Geological Survey Open-File Report, 170 p.

Darrell, L.C., Hazelwood, B.K., and Schwarz, G.W, in press, Comparison of loads and trends in total nitrogen, total phosphorus, and suspended material for the Potomac River at Chain Bridge, Washington, D.C., 1985-95, Prepared in cooperation with the Metropolitan Washington Council of Governments.
Department of Environmental Programs, Metropolitan Washington Council of Governments, 1987, Potomac River Water Quality 1985, Conditions and trends in Metropolitan Washington: Washington, D.C., [variously paged].

Fishman, M.J., and Friedman, L.C., 1989, Methods for determination of inorganic substances in water and fluvial sediments: U.S. Geological Survey Techniques of Water-Resources Investigations, book 5 , chap. A1, 545 p.

Friedman, L.C., and Erdmann, D.E., 1982, Quality-assurance practices for the chemical and biological analysis of water and fluvial sediments: U.S. Geological Survey Techniques of Water-Resources Investigations, book 5, chap. A6, $181 \mathrm{p}$.

Gilroy, E.J., Hirsch, R.M., and Cohn, T.A., 1990, Mean square error of regression-based constituent transport estimates: Water Resources Research, v. 26 , no. 9 , p. $2,069-2,077$.

Gilroy, E.J., Kirby, W.H., Cohn, T.A., and Glysson, G.D., January 1990, Discussion of uncertainty in suspended-sediment transport curves by McBean and Al-Nassri: Journal of Hydraulic Engineering, v. 116, no. 1, p. 143-145.

Glysson, G.D., 1987, Sediment-transport curves: U.S. Geological Survey Open-File Report 87-218, $47 \mathrm{p}$.

Gross, M.G., Karweit, M., Cronin, W.B., and Schubel, J.R., 1978, Suspended-sediment discharge of the Susquehanna River to northern Chesapeake Bay, 1966-1976: Estuaries, v. 1, p. 106-110.

Guy, H.P., 1969, Laboratory theory and methods for sediment analysis: U.S. Geological Survey Techniques of Water-Resources Investigations, book 5 , chap. $\mathrm{C} 1,58 \mathrm{p}$.

Guy, H.P., and Norman, V.W., 1970, Field methods for measurement of fluvial sediment: U.S. Geological Survey Techniques of WaterResources Investigations, book 3, chap. C2, $59 \mathrm{p}$. 
Hainly, R.A., and Siwiec, S.F., 1994, Nitrogen sources and measured nitrogen loads in streams in the Lower Susquehanna River Basin, Pennsylvania and Maryland [abs.]: EOS, Transactions of the American Geophysical Union, v. 75 , no. 44, p. 247, Supplement with abstracts for the 1994 Fall Meeting, San Francisco, Ca.

Hainly, R.A., and Loper, C.A., 1997, Water-quality assessment of the Lower Susquehanna River Basin, Pennsylvania, and Maryland-Sources, characteristics, analysis, and limitations of nutrient and suspended-sediment data, 19751990: U.S. Geological Survey Water-Resources Investigations Report 97-4209, 136 p.

Hamilton, P.A., and Shedlock, R.J., 1992, Are fertilizers and pesticides in the groundwater? A case study of the Delmarva Peninsula, Delaware, Maryland, and Virginia: U.S. Geological Survey Circular 1080, 16 p.

Helsel, D.R., and Hirsch, R.M., 1992, Statistical methods in water resources: Amsterdam, Elsievier Publ., 522 p.

Koch, R.W., and Smillie, G.M., 1986, Bias in hydrologic prediction using log-transformed regression models: Water-Resources Bulletin, v. 22 , no. 5 , p. 717-723.

Lang, D.J., 1982, Water quality of three major tributaries to the Chesapeake Bay: The Susquehanna, Potomac, and James Rivers, January 1979-April 1981: U.S. Geological Survey Water-Resources Investigations Report 82-32, $64 \mathrm{p}$.

Langland, M.J., and Hainly, R.A., 1997, Changes in bottom-surface elevations in three reservoirs on the Lower Susquehanna River, Pennsylvania and Maryland, following the January 1996 flood -implications for nutrient and sediment loads to Chesapeake Bay: U.S. Geological Survey Water-Resources Investigations Report 97-4138, $34 \mathrm{p}$.

Langland, M.J., Lietman, P.L., and Hoffman, S.A., 1995, Synthesis of nutrient and sediment data for watersheds within the Chesapeake Bay Drainage Basin: U.S. Geological Survey WaterResources Investigations Report 95-4233, 121 p.

Lindsey, B.D., Loper, C.A., and Hainly, R.A., 1997, Nitrate in ground water and stream base flow in the Lower Susquehanna River Basin, Pennsylvania and Maryland: U.S. Geological Survey Water-Resources Investigations Report 97-4146, $66 \mathrm{p}$.
Lizárraga, J.S., 1997, Estimation and analysis of nutrient and suspended-sediment loads at selected sites in the Potomac River Basin, 1993-95: U.S. Geological Survey Water-Resources Investigations Report 97-4154, 23 p.

Lizárraga, J.S., in press, Nutrient and sediment concentrations, trends, and loads from five subwatersheds in the Patuxent River Basin, Maryland, 1986-96: U.S. Geological Survey Water-Resources Investigations Report 98-4221.

Maryland Department of the Environment, Chesapeake Bay and Watershed Management Administration, Nonpoint Source Assessment and Policy Program, 1993, Chesapeake Bay Water-Quality Monitoring, River-Input Monitoring Component: Level 1 Data Summary Report: 1991, Technical Report no. 93-014.

1994, Chesapeake Bay Water-Quality Monitoring, River-Input Monitoring Component: Level 1 Data Summary Report: 1992, Technical Report no. 94-012.

1995, Chesapeake Bay Water-Quality Monitoring, River-Input Monitoring Component: Level 1 Data Summary Report: 1993, Technical Report no. 95-002.

1996, Chesapeake Bay Water-Quality Monitoring, River-Input Monitoring Component: Level 1 Data Summary Report: 1994, Administrative Report.

Maryland Department of the Environment, Chesapeake Bay and Watershed Management Administration, Water Resources Engineering Division, 1992, Chesapeake Bay River-Input Monitoring Program Quality-Assurance Report Data Collection Activities 1984-1991, Administrative Report.

1993, Chesapeake Bay River-Input Monitoring Program Quality-Assurance Report Data Collection Activities 1992, Administrative Report.

1994, Chesapeake Bay River-Input Monitoring Program Quality-Assurance Report Data Collection Activities 1993, Administrative Report.

Maryland Department of Natural Resources, Resource Assessment Services Administration, Tidewater Ecosystem Assessment, 1997, Chesapeake Bay Water-Quality Monitoring, River-Input Monitoring Component: Level 1 Data Summary Report: 1995, Administrative Report. 
Miller, C.R., 1951, Analysis of flow duration, sediment-rating curve method of computing sediment yield: U.S. Bureau of Reclamation Report, $15 \mathrm{p}$.

Ott, A.N., Takita, C.S., Edwards, R.E., and Bollinger, S.W., 1991, Loads and yields of nutrients and suspended sediment transported in the Susquehanna River Basin, 1985-89:

Susquehanna River Basin Commission Report, Publication no. 136, 253 p.

Phillips, P.J., and Bachman, L.J., 1996, Hydrologic landscapes on the Delmarva peninsula, Part 1 -Drainage basin type and baseflow chemistry: Journal of the American Water Resources Association, v. 32, no. 4, p. 767-778.

Preston, S.D., Bierman, B.J., Jr., and Silliman, S.E., 1989, An evaluation of methods for the estimation of tributary mass loads:

Water Resources Research, v. 25 no. 6 , p. 1,379-1,389.

Preston, S.D., and Summers, R.M., 1996, Estimation of nutrients and suspended-sediment loads in the Patuxent River Basin, Maryland, Water Years 1986-90: U.S. Geological Survey Water-Resources Investigations Report 96-4175, $69 \mathrm{p}$.

Reed, L.A., and Hoffman, S.A. 1997, Sediment deposition in Lake Clarke, Lake Aldred, and Conowingo Reservoir, Pennsylvania, and Maryland, 1910-93: U.S. Geological Survey Water-Resources Investigations Report 96-4048, 14 p., 3 pls.

Skougstad, M.W., Fishman, M.J., Friedman, L.C., Erdmann, D.E., and Duncan, S.S., 1979, Methods for determinations of inorganic substance in water and fluvial sediments: U.S. Geological Survey Techniques of Water-Resources Investigations, book 5 , chap. A1, 626 p.

Thomas, R.B., 1988, Monitoring baseline suspended sediment in forested basins-The effects of sampling suspended sediment on suspendedsediment rating curves: Hydrologic Sciences, v. 33 , no. 5, p. $499-514$.
U.S. Environmental Protection Agency, 1979, Method for the chemical analysis of water and wastes: Washington, U.S. Government Printing Office [variously paged].

1988, Chesapeake Bay Agreement, in Comprehensive research plan, an agreement commitment report from the Chesapeake Executive Council [variously paged].

1995, The State of the Chesapeake Bay, 1995: Washington D.C., U.S. Government Printing Office, $45 \mathrm{p}$.

U.S. Geological Survey, Mid-Atlantic District, 1983, Quality assurance plan for water-quality activities of the Mid-Atlantic District:

U.S. Geological Survey Administrative Report, Towson, Md., $52 \mathrm{p}$.

(provisional data) Estimated streamflow entering Chesapeake Bay-Total, accessed July 30, 1998, at url: http://md.usgs.gov/monthly/ bay.html

Verhoff, F.H., Yaksich, S.M., and Melfi, D.A., June 1980, River nutrient and chemical transport estimation: Journal of the Environmental Engineering Division, ASCE, Volume 106 (EE3), p. 591-608.

Vogelmann, J.E., Sohl, T.L., Campbell, P.V., and Shaw, D.M.,1998, Regional land cover characterization using Landsat Thematic Mapper data and ancillary data sources: Third EMAP Research Symposium, Albany, NY, April 8-11, 1997, Environmental Monitoring and Assessment, v. 51, p. 415-428.

Zynjuk, L.D., and Feit Majedi, B.L., 1996, January 1996 floods deliver large loads of nutrients and sediment to the Chesapeake Bay: U.S. Geological Survey Fact Sheet FS-140-96, 2 p. 


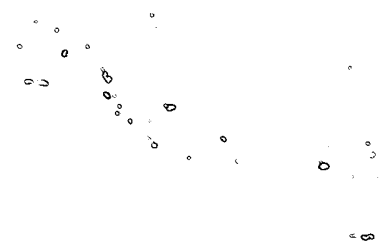

容 